\title{
SPROUTING FASCSIM OR NATIONALISM IN INDIA
}

${ }^{1}$ S M Nazmuz Sakib (Orchid- https://orcid.org/0000-0001-9310-3014)

\author{
${ }^{1}$ Graduate of BSc in Business Studies \\ School of Business And Trade \\ Pilatusstrasse 6003, 6003 Luzern, Switzerland \\ sakibpedia@gmail.com \\ ${ }^{1}$ Student of Department of Law \\ Dhaka International University \\ House \# 4, Road \# 1, Block - F, Dhaka 1213 \\ sakibpedia@students.diu.ac
}

\begin{abstract}
The qualitative study based on the theories of Fascism and nationalism will allow academic circles to do an in-depth analysis not only based on the hyper mass-media facts but also the objective approach from a scholar to look down upon. In this researched study, the present facts regarding Indian domestic political affairs falling upon the traits and principles of fascist agenda are discussed. The recent Citizenship act and the revocation of article 370 besides the spread of unreal propaganda, demagoguery, superior race mindset all these on going motives by Indian Republic has triggered the motivation to research deep into the facts if really Indian administration has moved onto the practical implementation of fascist rule or there is anything else which is behind the stage namely chauvinism. Moreover, it can be explained that this is an analytical cum predictive research that will only go for the evaluation of the real facts prescribing the fascism sprout but also will predict the future political dynamics in the light of these fascist movements spread across the region.
\end{abstract}

Keywords: Fascism, Nationalism, India, Indian Democracy, Democratic Problem, Indian Fascism 


\section{INTRODUCTION}

This research is based on the in-depth analysis of the study that whether it is sprouting Fascism, or the tendency of nationalism that has been increasing in contemporary India. The recent political trends in India are exhibiting that nationalism has been propagating to its extremes as the right-wingers are catching more power in the government. Though, it also has been analyzed that this extremist rise of nationalism phenomenon in India is turning into the threat of fascist rise. However, this research will put limelight evaluating into the other symptoms of Fascism that if these are also present in Indian politics and practiced in Indian society or not. For this purpose, the explanation of nationalism, as well as the signs of Fascism with the detailed explanation of both the phenomenal processes of isms, are elaborated in this research work.

This study has gone through the ruling regime ideology which is prevalent in India these days or from the last two rounds of government - BJP administration. As, BJP finds its root into RSS, so the detailed discussion over the missions and the institutions besides the mandate is given in the upcoming chapters which then be linked to check for the traits of the RSS led BJP government in India which actually is falling into the list of those fascist regimes which the world got threatened of or not. For this purpose, the main pillars of fascism are taken from the Stanley 
Jason study as well as the other scholarly articles which have given proper insight regarding the true colors of fascism and fascist leader as well as its fascist regime.

Furthermore, after proving each pillar existence or absence in the state affairs of Indian republic, this study has analyzed the regional implications of this rising wave of fascism. Because, if its really this fascist behavior aggrandizing in the Indian political motives then, it will surely want to engulf its neighborhood into its vicious circle, and Kashmir lockdown and plans regarding it like ethnic cleansing of Muslims from Kashmir which is a popular gesture and connotation in this aspect causing the whole piece of land ruled by India is one of the most vivid instance which can be relatable to this Hindutva and fascist agenda which will be explained later in chapters of this research study.

Moreover, the foreseen dynamics in region as well as in India will also be discussed. My thesis will have its closing remarks which will be my analysis regarding the scenario. I will also present the ending my research work with the way forwards that if it is just nationalism or fascist reality is face covered then, what should we as a neighboring nation, international community and the safeguards of human rights do for shielding this entire region from upcoming vicious havoc in the form of dissolute fascism.

The qualitative study based on the theories of international relations i.e. Fascism and nationalism will allow academic circles to do an in-depth analysis not only based on the hyper mass-media facts but also the straight objective approach from a scholar to consider. Moreover, this research is time-scaled with the facts since the inception of RSS and India. It can be explained that this is an analytical cum predictive research that will only go for the evaluation of the real facts prescribing the fascism sprout but also will predict the future political dynamics in the light of these fascist movements spread across the region. 


\section{PROBLEM STATEMENT}

The statement of the problem which I encountered while selecting for this particular thesis is that there is a lot of confusion that if Fascism is really sprouting on Indian lands or it is just the rise of the peak of nationalism. Is it the Hindutva nationalism hype only, or will this hype be practically applied over the scene causing the massive genocide of which the historical facts of Fascism had resulted in the past under Nazi-Germans?

\section{HYPOTHESIS}

Ho Sprouting fascist symptoms are engulfing India with bad nationalism

$\mathbf{H}_{1}$ Extreme nationalism is good for a state like India as it will bind the state together, so bringing prosperity.

\section{RESEARCH QUESTIONS}

a) Is it rising nationalism in positive form or bad nationalism resulting in fascist trend over the whole Indian socio-political and economic level?

b) Which symptoms of Fascism are present in India?

c) Will this rising Hindutva nationalism be the cause of genocide in India?

d) What are the regional consequences, as well as the constructive and destructive implications of this sprouting phenomenon? 


\begin{abstract}
AIMS AND OBJECTIVES
The aims and objectives of my research work will deal with the analysis of the facts that whether it is the rise of fascist tendencies or only the accrued nationalism, which is engulfing or spreading all among the Indian nationals. This research will provide the deep-down analysis for the fact that in which direction does the people and the state authorities of India are heading towards. The main aim of this research work is to uncover and unleash the facts that whether India is really following steps of Fascist Hitler or is just furnishing itself with embellished form of nationalism.
\end{abstract}

\title{
SIGNIFICANCE OF THE STUDY
}

This research paper will contribute best to the recent scholarly literature as the world is more inclined in contemporary times to the trends of rising Fascism and discussion over good or bad nationalism's extreme tendencies. From this study, the social circle of the academic level will be benefited. The analysis of Indian political trends. This study will certainly aid in enhancing the field knowledge regarding implementation over area studies and making it distinguishable that which theory fits unto the perspectives of rising trends of chauvinistic surge in south Asia specifically and mainly in India which most of the learned society thinks that regional competition has given a might to Indian political administration to rule out the fascist agenda on the overt basis leading gradually to the ethnic cleansing of Muslims and degradation of its lower caste class. Although the way forwards to handle this situation are also of great benefit for the think tanks to bend their policy frameworks in accordance with that to smoothly deal out the issue with minimum violations to innocent human masses under harsh Indian administration. 


\section{THEORETICAL FRAMEWORK}

Any research cannot be completed without its solid foundations take from some already authentic sources and the basic structure provided by the scholarship of that area of study. So, my research work is also just not solid if it is not based on any theoretical framework which will in turn provide it a proper structure and flow of information to be gathered in a direction. Thus, I have opted to use fascism and nationalism as the theoretical basis for my research work. These two theories will be utilized in the sense of their applied knowledge being practiced by the Indian administration in their state.

As the topic of this thesis work elucidates, the framework or the foundational basis of this research will be based on Fascism as a grounding theory side by side, taking nationalism as a supporting theory as well. Both theories will be utilized to support the arguments in this study. The whole research work is elucidating which theory implies at its best to the political stations lately. The philosophy of nationalism has its grounds instilling the vigor into the nation regarding enhancement of their national worth and morale while the other theory which is the extreme feature of nationalism and thus be recalled in the bad terms is the fascism which enhances the racial consciousness to such an extent that it develops and promotes the hatred in the hearts of a particular race in the nation against the other race or the community which can be differentiated on any basis most probably the religious basis and on racial grounds like Germans and Jews conflict led to genocide of Jews was a fascist trend syringed in the sub jugular vein of the masses or German nation state. 


\section{RESEARCH METHODOLOGY}

The research technique, which is followed in this research paper is such that the data collected is through qualitative analysis of the secondary data present on the online databases. This research is actually an analytical study for determining the sprouting of Fascism in India with the help of theories as a ground basis.

The technique for analyzing the data used for the peculiar research work is the content analysis and theme analysis with the usage of which the general information and their theme communication are observed and analyzed beside the huge volume of qualitative data is gathered from internet libraries and journal articles in addition to some soft copy books retrieved from international library book shelves.

The type of research which this thesis can be classified as is the exploratory and a bit of explanatory research type which aims to explore the major aspects under the rulings of the particular theory being practiced $n$ India and explanatory in th sense that it has shed a bit of light on the impacts and effects of practicing model of theory and then gives way forward to resolve the issue out of the state. Whereas it is a descriptive research with qualitative data used in which no group is controlled but just data is gathered without having interference with research variables which are at this point the political actors in India.

However, as far as the time scale, sampling and location of this study is concerned, the data is gathered on the basis of non-probability sampling in which the just Indian political affairs and situations are concerned, thus it can be said that it's a case study over India in the perspective of matching and unmatching the circumstances with theories of international relations. Henceforth the concluding remarks are only concerned with this particular state substance in the real-world laboratory settings.

Furthermore, as far as the timeline for this researched work is concerned the research methodology to design the research questions of this thesis lies in the fact that it was designed in 
accordance to longitudinal research studies in which I have gathered data from different point in times of the Indian political history making it relevant to the subject matter under discussion.

Moreover, this research design is fixed with its subjects, its time scale which is since the inception of India and location which has enabled me to measure and test the facts present in the Indian politics and give a generalized opinion regarding the practice of a theory in their political and domestic societal affairs. 


\section{LITERATURE REVIEW}

One of the articles by Robert Reich explains what good nationalism is and what is known as bad or negative chauvinism. He explains that when the society or a state moves to adopt positive chauvinism, then that society is more tolerant and likes to promote best for the other world too (Reich, 2001). While according to Reich, the negative or bad form of nationalism which is promoted in any state or society then, its people seek the rest of world involved in zero-sum thus the radical form of realism is propagated in that state and its people which makes them think their nation-as an ultimate nation for being considered great, thus authorities try to feed in the very fears into the minds of their masses to upsurge this wave of negative nationalism in their state.

In the news article of Geeta Pandey, it has been explained that the world is seeing the strongmen coming into power in their states, which many analysts have called to be observing the spread of fascist tendencies with rising nationalistic leaders victories to authority chairs. Furthermore, among these powerful political leaders coming into power is also Prime Minister Modi of India. Geeta Pandey also claims that many state institutions are showing their subjective approach towards promotions of nationalistic mindset and Indian military forces, which may consequently be deduced that India is facing the rise of Fascism as the support for the right-winger is seen to be up surging among the nationals of the state (Pandey, 2019).

In the journal article by Kalim, it has been explained in the light that the 2014 parliamentary political decision in India diminished Congress gathering to just 44 seats in the lower house, enormous blow for a gathering, whose history is necessary the nation's established account. In the last parliamentary political race, the Congress gathering surveyed just $19.3 \%$ of the votes declining from $28.6 \%$ in 2009 , while then again, the fundamental conservative gathering, for example, BJP (Bhartiya Janata Party) won 282 parliamentary seats and $31 \%$ of the national votes. The outrageous conservative associations have, without a doubt, turned into the focal post of Indian legislative issues. Most unmistakable among these associations are RSS (Rashtriya 
Swayamsevak Sangh), BJP, VHP (Vishva Hindu Parishad), Bajrang Dal and Shiv Senna. The point of this examination is to feature the ongoing ascent in extraordinary conservative Hindu associations and to look at their thoughts and theory concerning Indian history and culture (SIDDIQUI, 2017).

Another article (Chattopadhyay, 2009) that has put light on this issue of rising fascist $n$ nationalist tendencies highlighted the development of a homogeneous Hindu personality implied invalidating any thought of class and station divisions through token signals while holding an upper-caste and upper-class authority. M. S. Golwalkar, the second incomparable pioneer of the RSS, in his book We, or Our Nationhood Defined, respected the occasions of Kristallnacht, and said that the Germans had demonstrated that two countries could not live in one nation. During the long rough stretches of Partition, the Hindu communalist associations made an offer for power, yet the homicide of Gandhi by a Hindu communalist prompted solid government activity, and to a decrease of the associations. The procedure of the RSS was, at that point, one of the profoundly infiltrating common society. So Golwalkar got the restriction on the RSS revoked by promising the legislature that it would stay a "Social" association and would not challenge decisions. To dodge the limitation on governmental issues, the RSS, with the assistance of likeminded Hindu communalists, set up the Bhartiya Jan Sangh, an activist right-wing communalist gathering requiring an akhund Bharat; a free Indian atomic arms stockpile; profound antagonistic vibe toward Muslims, Christians, and socialists; a dismissal of majority rules system; and embrace of monetary progressivism. RSS obstruction prompted the inevitable separation of the Janata Party, however, in the process, the BJS reappeared as the much reinforced Bhartiya Janata Party (Chattopadhyay, 2009).

The newspaper HuffPost also wrote about this sprouting wave of Fascism around the world highlighting India also as one of the states, and it described that as of late, there had been various articles and articulations declaring that Fascism is ascending in Europe and that Donald Trump is an American case of Fascism. Buy in Now The charge of an ascent in Fascism originates from a significant misconception of Fascism. Fascism contrasts with patriotism in two significant 
manners. To start with, fascists did not see self as assurance an all-inclusive right. The privileges of different countries to their very own country condition was, best case scenario, vague to the fascists. Fascism was an attack on the privilege of countries to seek after their personal responsibility and a height of the fascists' entitlement to seek after it dependent on a statement of their countries' inborn prevalence and directly over principle. Fascism without the tyrant, without the disposal of races, without concealment of free discourse and the privilege to gather, is not Fascism (Friedman, 2017).

According to Mohammad Farooq and Umbreen Javaid in "Suspension of Article 370: Assessment of Modi's Kashmir Masterstroke Under," (2020) in Global Political Review, "The foundation of Rashtriya Swayamsevak Sangh (RSS) during 1940-1944 in the territory of Jammu and Kashmir cleared path for the execution of Hindutva belief system. With the ascent of BJP in the middle, Prime Minister Narendra Modi nullified 'article 370' taking Kashmir from its uncommon status on 5 August 2019. The purported 'Modi's masterstroke' is planned for changing over Muslim lion's share into a minority. The move has incited across the board open fights in the district, prompting the inconvenience of delayed time limitation and suspension of essential human rights in the state. This paper would feature the impacts of Hindutva belief system and the effect of the ongoing 'Modi's masterstroke' on the district. It would likewise investigate the job of RSS sponsored BJP in making a 'real existence detainment' circumstance for the Muslim larger part state" (pp. 1-8).

Albright wrote in her book about this rising surge of Fascism in the world and warned the world about its engulfing tendency. She is mindful so as to caution against the unpredictable utilization of the expression "fascism," and she appropriately starts this book with a discourse of its legitimate use and importance. Starting with the beginnings of the term in the mid-twentieth century, she follows the improvement of Fascist systems and pioneers who advance Fascism, from Mussolini and Hitler through Stalin (who seethed against Fascism while rehearsing it to a propelled degree) through to the present. Erdogan, Orban, Milosevic, the Kim line, and Putin are a portion of the many rehearsing Fascists Albright covers. Donald Trump has a section 
committed explicitly to him; however, Albright is not composing a divided screed using any and all means, simply examining the man's conduct and activities and exhibiting their upsetting similitudes to pioneers who obviously practice Fascism. Maybe the most significant parts are the last two, wherein Albright lists the peril signs for the United States and the world and gives a progression of inquiries to pose and steps to take for concerned residents (Passmore, 2014).

On 2018, in "The Return of Fascism: Youth, Violence and Nationalism” in Taylor \& Francis Educational Philosophy and Theory, Michael A. Peters wrote, "In dealing we fascism we must understand that it is a political doctrine that subordinates the individual and the rights of individuals to the all-powerful state and national advancement. It discourages freedom of speech and does not believe in peace. In subordinating everything to the State it champions a concept of duty, spirituality, youthfulness, and obedient submission. Its xenophobia, ultra-nationalism, racism, masculism and militarism not only sets itself against liberalism and Marxism, but also helps explain why contemporary identity politics that is based on the extension of rights and equality for all is so antagonistic to fascists" (pp. 674-678).

The book by M.S. Gulwalker, named "We and Nationhood defined," gives a thought of what a country ought to be by an individual who is viewed as one of the significant effects on present head administrator. I read the book to comprehend the RSS philosophy and to discover whether they have any saving grace. Skirting on to despotism, the perspectives introduced in the proposition are a work of loathe. Golwalker's hatred of Muslims and the British alongside an enlarged pride of the Hindu race is hazardous. He thinks what makes a country is a closeness of religion, language, culture, race, and goals. Regardless of India not fitting into any of the elements of this definition, he legitimizes that India has a solitary religion, language, culture, and race naturally. His perspectives about minority rights and the subsequent isolation are just beneficial thing in the entire book. Be that as it may, his thinking is too defective to be in any way paid attention to. 
What is in question is not just the Indian Dream. What is in question is the spirit of India. Through 25 sections and 550 pages Constitutional master, Supreme court legal advisor, and writer of over twelve books, A.G. Noorani portray how a mutual belief system takes shapes in current India, its adherence towards Nazism and dictatorship, reveal its demonstration during freedom second, and how RSS advance with Ram. Noorani's examination exposes the political aspirations of RSS. Even though RSS is an association with no constituent support, it holds the most frightful political plan that is the creation of a 'Hindu Rashtra.' In a period where India's dreams had been changed from tagorean 'Thought of India' to Savarkar's Hindutva, the book will give an away from history. Interpreting RSS implies deciphering one of the biggest fear monger association, it is tied in with concentrating how India's general public become so mutual and seeing how this nation turned into a Jurassic Park with two dinosaurs. At the point when equity is hampered to 5 Acres, and Ram sanctuary becomes a fact in a common nation, it ought to recall that RSS had killed the genuine smash of India in 1948 on January 30. Nevertheless, then, in spite of its compass and apparently overpowering political impact, the creator shows that the RSS can be vanquished. The spirit of India can be safeguarded.

In the book " before the night falls, fascism bodes in India" (Panikkar, 2003), these papers of Prof. Panikkar written over the most recent ten years think about the heap manners by which the Sangh Parivar has sought after a fundamentalist plan, especially in the social and political domains. They additionally endeavor to comprehend the explanations behind the inability of the mainstream powers to stem the tide of communalism and investigate the potential manners by which a counter social development can be initiated. An unquestionable requirement read for all in request to emphasize the full plan for secularism once more on the off chance that it is to be a nearness in Indian political and public activity. 
In "FASCISM IN INDIA-DEBATING RSS-BJP POLITICS” (Puniyani, 2017) it is explained, Fascism in Europe came as a horrific phenomenon where ultra-nationalist political ideology accompanied by targeting of minorities, rise Of a supreme leaner anti smashing of Popular movement-led tithe torture and massacre ${ }^{\circ}$ Marge section of the population. Democratic rights stood to suspend in these regimes. The authoritarian political ideology and its rulers had a mass base, which gloried the constructed past) The situation developing In India from IBM decade, more so horn last couple of years yes, many features which give the semblance of these regimes. The nature of this phenomenon is under debate for quite some time. Some Like Prakash Karat of CPI (Marxist) characterize it as 'mere authoritarian' while many others argue that it is fascist. The characterization of (1255-131 page) has a lot of Implications on the tops of political alliances to be forged by secular-democratic forces. This compilation aims to put together different articles, which unravel, politics of RSS-BJP-Modi.

According to Dr. Omer Farooq Zain in "Marginalization of Muslim Minority in India," (2009) in Pakistan Journal of Social Sciences, “India's profoundly strict - ridden air, loaded up with collective hostility, incendiary discourses, wrongdoings against minorities and the plan of Hindutva has been floating away the Muslim minority from the standard of the national existence of India. The Indian Muslims who structure roughly 16 percent of the complete populace, have been exposed to constant weight and have been demolished from places of significance in varying backgrounds. Purposeful endeavors have been made to deny them from their essential human rights. The Indian Muslims carry on with an existence of complete weakness and are being denied their Indian citizenship in various manners. Regardless of making innumerable commitments to India in practically all circles of life, the Muslims of India get themselves progressively powerless and critical about the potential outcomes of a monetary, socio-social, and political inspire in the common Indian culture. This investigation would attempt to inspect the goal conditions that spark public purging in the Indian socio-political setting. The examination will likewise focus on the theory that Indian state built exercises through its resistance organs introducing to the world, the Indian Muslim's political cognizance about their reasonable presence, as an indication of Islamic fanaticism or 'fear based oppression against 
Indian organization' in order to legitimize Indian state suppression and collective viciousness against the down-trodden honest Indian Muslims" (pp. 101-106).

Examinations between the Sangh Parivar and interwar European fascisms are inescapable. The authors of the Sangh were inspired by, and copied and adjusted, those fascisms (Casolari 2000). The Parivar's proliferating job in Indian legislative issues likewise intermittently proposed the examination, whether to legislators, for example, Indira Gandhi in the 1970s or to intellectuals after the destruction of the Babri Mosque (Sarkar in the volume being evaluated; Ahmad 1993; Basu et al. 1993). Other researchers have scrutinized the importance of the examination (Vanaik 1994; Jaffrelot1993), however, not phenomenally successful (Desai 2016). While ideological groups have regularly occupied with comparative political strategies - let us confine ourselves to Sanjay Gandhi's Youth Congress, and the1984 slaughter of Sikhs or the Shiv Senna's long record of association and Basti-busting — no gathering's exercises have so methodically inspired correlations with fascism as those of the gathering of Hindutva (Desai, 2016).

On 2018, in "Politics of Fake News: How WhatsApp Became a Potent Propaganda Tool in India" in Media Watch, Gowhar Farooq explained in his paper that while the Internet and various social media applications have made it simple to create and spread different information, they have likewise made it conceivable to disperse fake or counterfeit news to masses. With more than 200 million dynamic clients in India and developing, WhatsApp's scope and highlights settle on it a top decision to spread phony news. This impacts general conclusion in India as well as now and then made a frenzy and affected to savagery. This paper investigates how political propaganda is sold through the WhatsApp as 'news' (fake/counterfeit news). It additionally investigates what makes the WhatsApp such an amazing application in the Indian setting, how individuals use it, and how existing laws in India make it hard to follow the beginning of the phony news" (pp. 106-117).

This paper (Banaji, 2018) investigates the interconnections of Hindutva fascist collections in India and semi orientalist talks. History and sound judgment are re-composed through varying 
media correspondences to speak to one area of a hazardously part Indian open and neoliberaltouristic reasonableness somewhere else. Edification way of talking of progress, majority rules system, and innovative advancement are obviously exemplified by WhatsApp gatherings, electronic democratic machines, and laws to secure cows. Casting a ballot-as a marker of votebased citizenship - turns into a disguise, ensuring a resurgent far-right Hindutva (Hindu fascist) system under the aegis of Narendra Modi and the BJP. Station Hinduism's relationship of cows with gods, and the ban on meat-eating in specific renditions of strict practice, are utilized as appearances for unbelievable savagery against Muslims, Christians, Dalits, and common laborers/lower standing Hindus. Savagery against the individuals what dissent's identity is justified as enthusiastic. Hindutva's commonplace and stupendous varying media talk overpower open correspondence. Its outcomes are a type of vigilante citizenship that is set apart on the assortments of dead casualties and of vigilante publics fit to be activated either in ethno-social brutality or its protection and repudiation. In the interim, pulled into India as a vast market, Western governments and organizations have connived with the Hindutva system's selfadvancement as a bastion of improvement.

Furthermore, more literature review will be presented in my thesis is written after reviewing the literature from as many sources as possible including various e-publications, online journals, newspaper articles as well as YouTube videos side by side keeping a deep concern towards the study of books written on nationalism, ultra-conservatism, Fascism and the rising trend of these isms in the world which are great sign auguring possibility bringing down catastrophe for the world politics which consequently may result in changing the world order. 


\section{SCHEME OF STUDY}

Chapter 1: Fascism Conceptions And Misconceptions - This chapter will discuss the fascist principles that are what are those measures upon which any state is called to be a fascist and what are the general misconceptions which are generally trolling over online sources. This chapter not only discusses the definitions underlying both theoretical perspectives besides this it also showers its bliss upon the traits and classifications of both nationalism and fascism as political perspectives implemented practically in the societies.

Chapter 2: Ideology of the ruling regime in India - This chapter describes the very ideological beliefs on which Indian administration has been working on and instilling it in the minds of its masses since it inception. The ideology cult of Rashtriya Swayamsevak Sangh and Bhartiya janta party under the headship of Sangh Parivar has been described in detailed in addition the cultural vitality of both this paramilitary organization and the political party at front respectively is analyzed.

Chapter 3: India: Sprouting Fascism or Nationalism? - The third chapter of my research work will be based on trying to seed out the distinction between nationalism and Fascism meaning by which of this theoretical perspective can be seen in India lately, and is being cultivated and harvested in India for a long time but recently have seen a huge wave thrust.

\section{Chapter 4: Regional Implications of Indian Fascist Movement \& Foreseen Possible Dynamics}

in the Region - This chapter will help in understanding that what are and will be the implications of these fascist movements, which are rising in India, affecting the regional political dynamics. Moreover, this chapter will also shed its light upon the stances taken by the international community and the neighboring states of India regarding its political affairs if leading towards the fascist agenda. This chapter will evaluate the possible future dynamics of the South Asian region in which India is a hegemon because these trending fascist movement if become successful in India then the dynamics of this region will surely be different from the contemporary regional politics. 
Chapter 5: Closing Remarks \& Dedicated Way Forwards - this chapter will give the suggestive measures that how to contain the ultranationalist feelings to be propagated in the states as the negative nationalism will lead to building the cornerstones for fascist agenda which can roughly be the sign to disastrous consequences for the world politics. However, the concluding remarks of this research will make it know whether the hypothesis augured before in the research work is proved, or there are antithesis proofs aside from the hypothesis given above. 


\section{CHAPTER 1: FASCISM \& NATIONALISM - CONCEPTIONS AND MISCONCEPTIONS}

\section{DEFINING \& CLASSIFYING FASCISM}

Before moving towards the concepts and the misconceptions of Fascism, which are generally available on the most surfing and readable sources, i.e., the internet, I would like to define Fascism in two ways. In my point of view, there are two definitions of Fascism one is "Moral Fascism," and others I would like to name an immoral aspect of Fascism as "Dissolute Fascism."

Moral Fascism can be defined as the type of Fascism which calls for such political will and ideology rather bringing out such a firm and resolute political framework which encourages the state citizens to have strengthened nationalistic surge, will to be a superior power, engaging in international socio-political and economic relations, making own nation grabs larger portion encompassing in terms of land too, and be a successful race cum nation in the world.

Whereas, dissolute Fascism can be understood as the aspect of Fascism, which alludes to a hugely negative dimension for fascists known all over the world. It is the aspect which depicts to much extent negative nationalism pumping the state nationals to suppose their own race as the most superior one like, for instance, Aryan race as Indian Fascist/extreme nationalist call themselves as. This aspect of Fascism just not only deals with negative or extreme forms of nationalism but also, there are various other such tactics, which makes it different from the moral aspect of Fascism, i.e., moral Fascism.

\section{CONCEPTS \& CLASSIFICATION REGARDING NATIONALISM}


When the term nationalism is repeatedly used in this research work, the clear concepts are elaborated in details as; a neat concept of nationalism which I have borrowed to base my research work on is from encyclopedia Britannica (Kohn, 2020) which says it in a super fine way that nationalism is an ideology in which the phenomenon of showing besides sowing loyalty to the nation-state and its interests outstanding the interests of any other group of people or organization.

Now, nationalism can be classified as 'good/positive nationalism' and a 'bad/negative nationalism.' A good nationalism is likewise that phenomenon of propagating ideology which only seeks to have positive outcomes for the state strength and stability by practicing the modes which are in real good for state growth; that is it does not give air to radical or extremist ideas and practices to be followed to make a nation great or national identity superior to the rest. Moreover, it is a type of nationalism that tends to unify the diverse ethnicity of the populace that is a state which does have ethnopolitical inclusion (Sam Winter-Levy, 2018), and then it means that a specific state is implied on the business of promotion of good nationalism.

Besides, this definition as mentioned earlier of good/positive nationalism is also elucidating towards the explanation of the bad or negative form of nationalism, which can be expressed as the kind originating from the right-wing in the early 1920s to 30s (ibid.). To the extreme end of negative or bad nationalism, the reason this name calls it is that it triggers the state nationals or group of people to for grant in the name of nationalism and spread the waves of fascist tendencies, suppressed media only displaying the content to intensify the anger against other, ethnicities, caste, races or nations, considering one's own national identity as the best one.

Consequently, this bad form of nationalism or its negative aspect is referred to as Fascism in some respects. And then this negative nationalism, when it reaches its epic of intensity, be termed as dissolute Fascism in this paper. While, on the other hand, when negative nationalism is used for some good and moral purposes for raising let it be said a downtrodden race in any state or protecting one's own national values which are at risk of extinction or mutation, then this 
aspect of Fascism is termed as moral Fascism as it can be justified that it was the need of the hour to take that step of moving towards bad reputed but still the moral aspect of Fascism.

Hence when the definitions are clear for founding basic stature to this research work, this chapter will now explain the misconceptions about Fascism that are present around lately. There are fourteen pieces of information spread all around the internet or digital sources, which are said to be proven false about the theory of Fascism in practice. Nevertheless, before that, this study will put limelight to the basic principles of Fascism, which are prerequisites for any government or group to be called fascist.

The basic and the most primary feature of Fascism is the absolute authoritarian regime in which the leader of the state of nationhood should have absolute power to rule over his masses. The second central discourse through which a fascist regime can be dignified from the regular or democratic regimes is that the nationals under fascist regimes have an unswerving sense of pride in their race or nationality characterizing it with the negative or bad form of nationalism as per the explanations mentioned above for nationalistic drives to be present around the world. Albeit Fascism is called an ultranationalist far-right movement spreading across the globe in today's world.

\section{TRAITS OF FASCISM}

There are ten main pillars of Fascism, as explained by the renowned scholar of philosophy and propaganda - Jason Stanley, on which the foundations of this theory lie and can be seen in the applied world politics (Stanley, 2018). These points are in the following heads:

\section{MYTHIC PAST}

This point signals to the concept that Fascism is such an ideology that gains its glory, adding more to appeal the historical successes, grandeur, and fame of that particular nation from the past by relating its features or characteristics being extricated from that super awesome creed of their ascendants. It is in the absolute nature of Fascism that the fascist leader unites its scattered public 
in the name of their glorious past once they had centuries ago. This glorious past linkage leads to rationalism roots in which the leader always tries to link each thing to the highest traditions of their race.

\section{EVERYTHING IS INVERTED}

The culture of fake news is the most prominent example of inverted every little thing around in the nation-state ruled by the fascist trends. There are various kinds of propagandas which are utilized as a key to spreading the voice of fascist leaders (Stanley, 2017).

\section{DEMAGOGUERY}

The featured characteristic of fascist is the demagoguery which means that the leader in authority or the ruling party in the nation-state strikes the touching desires of the ordinary segment of the state society, i.e., middle people who want to change their lives and wants for some hope in competent authority but are demonized sweetly and smoothly by the authoritarian cum fascist dictator. So, demagoguery is one of the ways for political opportunists to pave their way to meet the ends rather than rational policies.

\section{ANTI-INTELLECTUALISM}

Steve Banan said, "its emotion and rage, which get people on polls, which says get elected on Locke her up and build the wall." Hitler said you want your propaganda to appeal most to the least educated people. The target of Fascism is always the weaker class, whether it is weak in its intellect or its monetary power.

\section{UNREALITY}


This trait of fascism is linked with smashing the truth before it reaches the public. The fascist regime tries its best to let not the public know the real facts. The authoritarian regime practices this phenomenon for the reason to cultivate and stabilize their loyalty to the state. Here obsession for the plot is appropriate.

\section{HIERARCHY}

In fascist politics, a dominant group is better than everyone else - "Hierarchy. Rather than liberal vote-based systems, which depend on opportunity and uniformity, fascism cherishes a prevailing group's customs as the unequivocal guideline (Stanley, 2018)."

At the point when Stanley discusses "hierarchy" when alluding to a transcendent group's customs overwhelming society, he is truly discussing two things - a prevalent culture and a dominating worth framework. He's discussing the way that there's an overwhelming social character in a nation, with its own arrangement of qualities, which appears to sit at the head of the various leveled stepping stool, and afterward there's different societies and customs, which speaks to minority groups, or new migrant groups, which will in general sit beneath the dominating social personality on the progressive stepping stool - particularly with regards to predominance in a general public.

\section{GREAT PEOPLE BEING GREATEST VICTIMS}

Fascist in the past were like the super loyal and the great people in the past who deserve respect for just for being the victimhood. In Fascism the dominant groups are the greatest victims like the men are the greatest victims of encroaching feminism, whites are the greatest victims of blacks, Germans are the greatest victims of Jews. Victimhood. All through fundamentalist legislative issues, the predominant group consistently depicts itself as casualties. Stanley said the Nazis said they were the survivors of the minority Jews. He said that Hungarian Prime Minister Viktor Orban held a worldwide gathering on the oppression of Jews in October 2017, during which he pronounced that Christians are the most mistreated group on the planet (Ibid). 


\section{LAW AND ORDER}

Law and order. The fascist government official guarantees a system of law and order not to rebuff real crooks, however, to condemn "off-worlders" like racial, ethnic, strict, and sexual minorities. "At the present time," Stanley stated, "we're seeing guiltiness being composed into migration status" in the United States (ibid.). As per Stanley, fascist lawmakers blossom with propelling purportedly explicit assaults against specific fragments of a populace, similar to "criminal" settlers or Jews, and then expanding that definition to incorporate the whole gathering.

There are such vast numbers of comments about this one. At the point when Stanley discusses "law and order" being something utilized by fascist legislators to condemn "off-worlders," there is some reality to that announcement. At the point when fascists, especially under the Nazi system, which exemplifies fascism, made laws that assaulted the Jewish individuals, just as different gatherings, they did precisely what Stanley claims they did (Stanley, 2018).

\section{SEXUAL ANXIETY}

Sexual uneasiness - Stanley said the fundamentalist government official consistently incites alarm around the danger of assault executed by off-worlder men against in-group ladies. "The specific danger is assault," he stated, "and afterward one makes dread among individuals by discussing assault, and later one attempt to assault individuals' reduced feeling of conventional masculinity by instigating anxiety about sexuality."

Something Stanley is in all likelihood discussing is the political right's idea that there are a few off-worlders (Muslims in case of India) that come here wrongfully, do not regard the laws, and carry out wrongdoing, including the assaulting of ladies. The perspicacity is that illicit settlers are a critical wellspring of wrongdoing in fascist nation. 


\section{VALUES COME AS DECADENT}

Sodom and Gomorrah _ the real values come from the heartland of the people in the city are decadent. Extremist government officials consistently find prudence in the open country and in humble communities, and never in urban areas with their blends of individuals, races, wantonness and leniency (Stanley, 2018)."

This is a truly intriguing contention that Stanley presents, since, what he's expression, in the most inconspicuous of language, is extremely about making a division in the nation between the urban communities, the exceptionally urbanized territories with significant levels of populace, and different regions of the nation that speak to suburbia, littler urban areas and towns, and the wide open where the country's food is created.

\section{ARBEIT MACHT FREI}

"Arbeit Macht Frei. Extremist lawmakers recognize out groups as lethargic, assault the government assistance frameworks and work coordinators, and advance the possibility that the group on top is persevering, the groups on the base are languid and channels on the state and ought to be compelled to work, in a perfect world for nothing (ibid)."

We should begin with the expression "Arbeit macht frei." This is a German expression that signifies "Work liberates you," and it was put at the passageway to vast numbers of the Nazi's death camps, including Auschwitz and Dachau. The Jewish individuals would ridicule this expression, on the grounds that there was nothing honest about it. They realized they wouldn't be discharged in the event that they buckled down enough and long enough - they knew this. What they can be sure of is that the main opportunity sought them was at the purpose of death, or on that day that the Allies would free them.

Stanley is utilizing this expression to attack those of us who think those subject to the administration, who are a piece of the social government assistance gives, ought to go out and make a big deal about themselves, quit being inactive, and accomplish some important work. 
"We should simply let the government assistance beneficiaries stay where they are. The way that we need those individuals to work, and take care of their fair share, instead of be a weight to all of us, the citizen, makes us like the Nazis, those extremists who told their detainees that "work liberates you."- the work shall make you free, the off-worlder is lazy, they are not just criminals but lazy and social Darwinism - it is all about winning (Reporter et al., 2020)."

Other than the Stanley features of fascism, the other main pillars of this ideology are given below:

\section{WARMONGERING NATURE}

A state which aims to pursue the fascist trends in its politics always shows itself as a warmongering country that always tries to wage war or deter with war waging or remain in clashes with the neighborhood.

\section{MEDIA IN-CONTROL}

The fascist regimes always are authoritarian regimes go with charm to control everything and guide it to the principles of what the state authorities want. Besides, media is one of the sharpest way to spread propagandas and conspiracy theories to mind wash the masses of the state bubbling their emotions towards the ultra nationalism, media also serves best in the interest of propelling this ideology as it's a early sign from which one can identify the state motives. It will always represent its state works as the world best deeds done by any government ever with high praise to state's military muscle and make it possible to project it at its best.

\section{PROTECTIONISM}

The mode of economy followed by the fascist states is protectionism in which state administration gain the public admiration by chanting for the protectionist measures in the economy and feed for the preservation of home industry. The trade tariffs are increased to their maximum limit is also a sign of fascist rise in the administrative affairs. 
Above are all the concepts which are linked when it comes to fascist traits and every scholar analyze these set of traits and characteristics in order to judge the state actions if going in that direction or not. However, there are some mis concepts or misapprehended thoughts regarding fascism and people mistakenly judge on that behalf. These misapprehensions are given below.

\section{MISAPPREHENSIONS REGARDING FASCISM}

As this chapter deals with concepts and understanding regarding the phenomenon of fascism, it will certainly put some light onto its recently spreading misconceptions which most people take that it is fascist thing although the things aren't as these are being perceived. So, there are various points concerned to which I would like to say, these are mere fallacies encompassing the trendy occurrence of fascism in the world. 
Fascism is commonly believed to be linked with increased nationalist tendency in a state. While the proper concept doesn't encompass the patriotism of chauvinistic tendencies among the masses but the idea of presupposing that race as the superior race a progeny of Aaryan race which is best in the generations o earth. Because it was something originally Nazis did believe too that they were the only superior race on earth having roots in Aaryan race. Thus, mixing ultra nationalism with the concept of fascism is itself a stabbing back action to this imperialistic thought of being belonged to a super Aaryan race.

Another point is that not every populist is fascist, but every fascist is populist which means that although the leaders tend to be populist (politician who tends to attract the attention of general community other than elite class of the society) but it commonly doesn't makes them associate with the fact that they are being fascist. However, the one with above-mentioned traits if hits with appealing speeches and vows for middle class and lay man of the society, it for surely means that this leader is fascist who is not only appealing the middle class as his target group but also fulfilling the other characteristics like being misogynist, past lover and idealizer with thoughts of super race existence.

Fascism is not the trait of left wingers and this is delusion largely present these days, but fascism is a characteristic of right wing who are conservative in their policies. They have traditional cult in their minds on which they try to cajole the ordinary man into its fallacies. So, this misapprehension should be removed from the mindsets that fascism is leftist, but it is actually rightist agenda.

Another biggest misapprehension is that its generally believed that fascism is same as Nazism. Although its true loophole in understanding both ideological phenomenon, Nazism is the offshoot of fascism which was originally developed by Mussolini, but German practiced Nazism was ideology just inspired from fascism for its super race concept. It was fascism which don't want the people who they don't like but it was Nazism which genocide them which they don't like. 
Fascism is not nationalism, but fascism is a negative form of nationalism or hyper-ultranationalism which considers supreme race only but no one else. Fascists are capitalist is another biggest common misapprehension. Nevertheless, the fact is fascist are the true protectionist administered as autocrats. Fascists are not religious is a mis concept which is also seen swaying in general public. Instead these are the actual cults which do entwine the religion with government affairs and take it to its intense form that if one would not accept their religion would not be allowed to live in their state or must be punished or be forced converted.

Moreover, it was all about the fascist traits and the misapprehensions floating in the society and needs to have ken eye on so that these must be pointed out in any state for an instance, India as this study will reflect upon its moves if towards fascism or not.

\section{CHAPTER 2: IDEOLOGY OF THE RULING REGIME IN INDIA}

In order to study and observe the political features and ideology being followed in republic of India, it's far more than a necessity to study in depth about the ruling administration its beliefs and cognizance which it gives to its followers in the state. Therefore, this chapter will mainly put stress on the ideology of BJP. The ideology of BJP syncs with RSS (Narayanan, 2019). Because the above-mentioned fascist traits lead to analyze most important thing that is the political mandates and the ideologies which are being followed in India. The political party which is in 
power these days continuing its second round of holding regime in India is BJP, which has the world largest recorded members following, i.e., 180M (Desk, 2019). This synchronization is mentioned clearly in the following heading.

\section{BJP IDEOLOGY AND ITS SYNCHRONIZATION WITH RSS IDEOLOGY}

The ideology of BJP mainly moves around the promulgation of positive secularism and valuebased politics showing commitment to the Gandhian approach. Basically, this party is a Hindu nationalist party but the Gandhian approach, which is reflected in article six of the party's constitution. Despite the fact, the 1988 manifesto exhibits that the BJP should be a religionneutral party, but its actions name BJP and RSS inline meaning to be ruling on the principles of Hindutva ideology.

However, there is another element of this party that also revolves around integral Humanism philosophy but, there is no translucent connection described between the Hindutva and integral Humanism ideologies that are present in the practices and on the theoretical terms (Narayanan, 2019). Whereas, when the name calls for Hindu fundamentalism, then one may also find the connection of BJP and RSS into this. As both of these parties promote Hindu nationalistic surge in the state, and this can be clearly reflected on the basic terms even if the name of these parties is deconstructed that is BJP is an abbreviation of Bhartiya Janata Party; the party of Indian people, and similarly RSS which is an abbreviation of Rashtriya Swayamsevak Sangh or in English is the National Volunteer Corps or force (Munson, 2019).

So, till this point, there is a bright contradiction between the party's manifesto and practices as well as its close bonding with RSS which has been since 1925 (Bajpai, 2014) highlighted for its extreme nationalistic agenda which calls its followers to practice self-defense techniques (Narayanan, 2019) making the Hindu race to be able to avoid any imminent danger and risk from any other religious followers and secure the land for Hindu nationals only(Bajpai, 2014). 
There are many events in the history of India which have indicated to the involvement of RSS in coordination with BJP as a ruling party on front end exploiting the rights of minorities and practicing Hindu nationalist, extremist, and fundamentalist activities in various parts of India naming to promote and secure the Hindu interest while endorsing Hindu nationalism among the masses.

The history of the root cause, which had triggered the Hindus for the formation of an organization for providing protection and services to the Hindu nation, only was the anti-colonial revolutionary person named Veer Savarkar. He was the one who published his book named "Hindutva: Who is Hindu?" In this book, he translated his idea of Hindu unanimity, transforming this segment of society into more persuasive emblem in the nation-state of India.

So, his first publication come up in 1923 in which he explicitly considered other religious bodes as the foreign presence and thus divided nation on the religious boundaries. Nevertheless, this book was not enough to answer the main question which it has itself left that how and on which modes does the Hindu nation-state should be founded and constructed on. Hence, in 1925, two years later, the publication of this book, Keshav Hedgewar, who was an upper caste brahmin, plastered the cornerstones of a nationalistic organization; Rashtriya Swayamsevak Sangh RSS), which became the renowned greatest xenophobic organization of Republic of India.

Furthermore, cutting a long story short, the workers and the promulgators of RSS got much influenced by the writings and thoughts of Savarkar, which has instilled the thought that Hindu men were effete. So, the Rashtriya Swayamsevak Sangh volunteers taken Hindu traditions into account and reworked on the basics adding two more Hindu nationalist fundamental precepts into that traditional Hindu model that were Sanghatan and Seva meaning by Hindu organization and service, respectively.

Keeping this view of effeminacy among Hindu men, RSS endeavored to respond against it and inculcate the manly personality traits as well as values in Hindu men. These RSS activists' units' range to above fifty thousand lately. These activists train men in achieving trait for discipline 
with well-practiced martial arts, liveried drills, and maneuvers. This Hindu organization was also assumed as the option to invigorate the errant principles of various Hindu fragments. Lately, RSS is practicing generalizing their orders as per their commands towards lower or inferior caste Hindus (Alder, 2016), for instance, withholding them from eating beef considering illegal both spiritually and legally to slaughter cow-mother.

\section{MISSION OF RSS}

This Hindu organization which has sowed the seeds towards the rise of Hindu chauvinism has a proper set of the mission to follow which is given below (Sangh, 2012):

In 2012, in "Vision and Mission - Rss: the Mission” as per Rss.org, it said Dr. Keshav Baliram Hedgewar envisaged, "The Hindu culture is the life-breath of Hindustan. It is therefore clear that if Hindustan is to be protected, we should first nourish the Hindu culture. If the Hindu culture perishes in Hindustan itself, and if the Hindu society ceases to exist, it will hardly be appropriate to refer to the mere geographical entity that remains as Hindustan. Mere geographical lumps do not make a nation. The entire society should be in such a vigilant and organized condition that no one would dare to cast an evil eye on any of our points of honor. Strength, it should be remembered, comes only through the organization. Every Hindu, therefore, must do his best to consolidate the Hindu society. The Sangh is just carrying out this supreme task. The present fate of the country cannot be changed unless the lakhs of young men dedicate their entire life to that cause. To mold the minds of our youth towards that end is the supreme aim of the Sangh."

\section{CULTURAL VITALITY}

This organization believes in the fact that Hindu culture is the real lifeline of Hindustan, which should be preserved no matter what. Subsequently, it is fundamentally vital Hindus practice their cultural traits and traditions as well as values taught to them by their Hindu culture and religion, 
which is a significant offshoot of Hindu culture in this case. The authorities believe of RSS that if the Hindu culture is not endeavored to be preserved, then it will be like perishing all the Hindu societal norms and values, which will resultantly only cause Hindustan as land to exit but no Hindu society.

For this purpose, this organization should support the growth and nourishment of Hindu culture to all over the territory, because when Hindu culture is expanded and practiced to its fullest to each corner of the territory then, it will tend to call Hindustan a nation in rational senses otherwise only territorial boundaries named with Hindustan will not be appropriately refer to the Hindu nation.

Therefore, the mission of RSS tends to preach the whole Hindu society that they should be sturdy and vigilant enough to cast the evil eyes off from their land, nation as well as culture. So, it can be said that the main motive of RSS is to make its Hindu nation such organized and trained with vigilance that no external rival elements should cast an evil eye on the morals of Hindustan and Hindus' goal of honor.

The propagator of RSS said that it should be recalled that it is only the strength that matters which comes just throughout the organization. Subsequently, it is an obligation towards every Hindu individual to endeavor for the consolidation of Hindu society. The supreme task is only being carried out by the Sangh Parivar. However, the future of this nation cannot be altered only by this effort but the lifetime exertions from lacs of dedicated young men towards this noble cause of consolidation of Hindu society and its upstream preservation. The superior aim of Sangh is to change the minds of the mindset of the Indian Hindu youth towards this noble reason - Dr. Keshav Baliram Hedgewar.

Although RSS narrates itself as a splendid, radiant diamond which is extending its influential beam everywhere unifying for the cause of Hindu Sangh that is Hindu chauvinist tendencies uproar, however, these point of views, if one sees on the official website of RSS, 
seem very appealing that RSS is doing all for an excellent cause for inspiring developments for Hindustan.

Nevertheless, the picture seems almost the opposite when the critiques are to be considered. For instance, the book of Abdul Ghafoor Majeed Noorani named "The RSS - A Menace to India" has been the latest edition of the critique published in 2019. This book, although was written by a Muslim law practitioner he has been living in India for the last eightynine years, and the is the author of many numbers of books. So, the credulous of his critique can be worth enough to be added in the same chapter after the elaboration of the RSS mission in the words of its propagators. This book has straightforwardly put the claim that RSS is a pure danger to the Indian republic and governs on the principle of authoritarianism and fundamentalism promotion.

According to Abdul Ghafoor Abdul Majeed Noorani in The Rss - Menace to India, "India is battling for its very soul. The Rashtriya Swayamsevak Sangh (RSS) is the most powerful organization in India today, complete with a private army of its own, unquestionably obeying its leader who functions on fascist lines on the Fuehrer principle. Two of its pracharaks (active preachers) have gone on to become prime ministers of India. In 1951 it set up a political front, the Bhartiya Jana Sangh, which merged into the Janata Party in 1977 only to walk out of it in 1980. In issue was its superior loyalty to its parent and mentor, the RSS, not the Janata Party. Within months of its defection, the Jana Sangh reemerged, not with the name under which it had functioned for nearly three decades, but as the Bhartiya Janata Party, deceptively to claim a respectable lineage. The RSS is at war with India's past. It belittles three of the greatest builders of the Indian State - Ashoka, the Buddhist; Akbar, the Muslim; and Nehru, a civilized Enlightened Hindu. It would wipe out centuries of achievement for which the world has acclaimed India and replace that with its own narrow, divisive ideology. This book is a magisterial study of the RSS, from its formation in 1925 to the present day. With scrupulous and voluminous evidence, one of India's leading constitutional experts and political analysts, A.G. Noorani, builds a watertight case to show how the RSS is much more than a threat to communal 
amity. It poses a wider challenge. It is a threat to democratic governance and, even worse, a menace to India. It threatens the very soul of India. Nevertheless, despite its reach and seemingly overwhelming political influence, the author shows that the RSS can be defeated. The soul of India can be rescued (Noorani, 2019).”

Up till now, the mandate and the ideology of RSS are cleared that it is a paramilitary wing of India which dictates the Hindu ultra-nationalistic waves in India calling for united Hindutva where Hindus be an only great nation to have a right to be there in Hindustan prompting Hindutva doctrine.

The above details not only explain the ideology being followed by the recent Indian administration but also it alludes to explain that how the Indian authorities are pursuing the fascist trends reckoning the mythic past and inculcating the ways to instill it in the veins of the Indian nation.

\section{CHAPTER 3: INDIA - SPROUTING FASCISM OR NATIONALISM?}

This chapter in this thesis will deal with investigating the fact that if the state government of the largest democratic state India hence for this purpose, the pillars of Fascism are described in the earlier chapter, which has discussed the concepts of Fascism. Therefore, this paper will discuss those pillars one by one in the light of events happening in India that if these are in line with fascist ideology, sprouting ultra-nationalism in concurrence with racist superiority mindset or it is just the nationalism for the sake of national good ad uplift. 
Is the regime in India falling for the physiognomies of Fascism to come true? This question can be answered in the context of the characteristics of Fascism, as aforementioned in chapter one. The following are the corresponding details if presenting the adherence to the fascist attitude in practice in the Republic of India.

Fascist leader reminds his nation of glorious past their race had once. The first and foremost pillar of the fascist ideology is that the peculiar nation which is following the fact that its leadership is reckoning to adherence with the glorious past of that particular nation or race towards which the state leadership harks back to stimulating the ultranationalist urge among the masses.

One such instance of glorious past can be clearly taken from the fact of Kashmir dispute where the Indian authorities tend to name the annexation towards Kashmir as a part of India raising the slogan "Akhund Bharat" which means the unified India which not only instigate as an appealing term to unite the Hindus under the flag of RSS ideology which foresees to make the whole subcontinent as per the ideology of Hindutva. The language of Narendra Modi also reflects the tendencies towards the provocation of ultra-nationalism like "Bharath Mata Ki jay," "shoot the traitor to the nation" and other such slogans which are injected in the veins of India in the name of Hindutva are "Oh motherland, sacrifice for you is like a life, living without you is death."

So, it can be deduced from the activities of an ideological following of BJP and its allies like RSS who promote Hindutva in India which is verily different from Hinduism, these actors in the Indian political climate promote and invoke the glorious past in the common man mind, i.e., to save India from the foreign antibodies (extraneous cultural cults \& religions) in the very land of Hindustan other than Hindus only.

Another feature of Fascism on which India fall so finely is the propaganda and the conspiracy theories which not only propagates the phenomenon of anti-intellectualism; as per mentioned by Jason Stanley, but also pinpoints the fascist regime trait of unreality and demagoguery 
emphasizing upon the spread of fake news around the state as well as such appealing vows are done to the state public which is meant for authorities to accrue in terms of power.

This is clearly expressed in the book " Hindutva and Dalits: Perspectives for Understanding Communal Praxis" (Teltumbde, 2005) that the Hindutva philosophy has taken uphold in India and is proving a menace to the races and segments other than dominant Hindu castes by inculcating the poison of appealing unreality, demagoguery, anti-intellectualism and mass-media control, subjecting Hindus as the victims of the non-Hindus which then serve as the cause of getting into power. Because hitting the hot nail would ultimately take them to the power serving chair and the only way to that is the projection of stance that the dominant Hindu caste or group that is mainly controlled by the Sangh Parivar is the one who can get the low caste Hindus out of this distress of unspoiled non-Hindus.

Although Swayamsevak Sangh projects that theoretically in official papers that it wants the union of Hindus despite the notion of touchable or untouchables but in practice, there are many numbers of events which ark this fantasy fall false. However, when these Dalits or such untouchable castes of Hindus as well as the non Hindus like Muslims and Christians but mainly Muslims when try to expose the real face of Sangh and their strategic notion through protests, then their voices are always culminated into silence through whips of torture. Besides this book claims of such tyranny in the actions of the dominant Hindu groups in India, which are practicing fascist trends, the coverage of the recent events is the speaking illustration of such brutality in the name of Hindutva.

However, the word Hinduism and Hindutva should not be confused at this point because both carry the same prefix that is Hindu. Because the very reason and best explanation which I have retrieved after the in-depth analysis of the publication at Asian studies organization by Arvind Sharma is that Hinduism is clearly a term depicting the religious norms and values, but Hindutva can be reflected like the way it is differentiated between Islam and Islamic extremism or fundamentalism. The paper by Sharma has even called Hindutva as the illicit son of Hinduism 
(Sharma, 2020) meaning by Hindutva is the offshoot which is developed by the extremist mindsets who wants to change the real gest of a secular society with the idea of the extreme form of Hinduism brainwashing the minds by polarizing the public opinion gradually making masses' emotions burn into the fire against the Muslims mainly and another non-dominant caste Hindus like Dalits and Christians.

The recent example can be quoted as the attack on the cow traders or transporters who are brutally killed or injured by the Hindu cow vigilantes. It has been recorded in the news and research articles as well as by the human rights watch that since Bhartiya Janata Party gained control of the Indian regime, the lynching against the cow transporters or in other words against the Muslims has taken a visible surge which is reflecting the Hindutva ideology working behind as practicing. Promising goal to fulfill for many years the Sangh Parivar ideology of Keshav and Gulwalker has been incited into the minds of these paramilitary or national Volunteer Core of India through the Indian peoples' Party or generally Known as BJP.

According to Madhav Sadashiv Gulwalker in We and Our Nationhood Defined, "To keep up the purity of the Race and its culture, Germany shocked the world by her purging the country of the Semitic Races - the Jews. Race pride at its highest has been manifested here. Germany has also shown how well-nigh impossible it is for Races and cultures, having differences going to the root, to be assimilated into one united whole, a good lesson for us in Hindustan to learn and profit by” (pp. 87-88) (Golwalkar, 1947).

Such maxims from the leaders on which the Junta relies so hard always take the masses into that psychological state, which will urge them to really do what Hitler did. Furthermore, it was evident in the variety of incidents happened which happened on the land of Hindustan out of which one recent is the rampaging attack on Jawaharlal Nehru University in which the lynching mob came and ran over the Muslim students like crushing peanuts raising the slogan "shoot the traitors to India." 
Moreover, it should be added here that there are various organizations which are affiliated to RSS and serve its purpose with Fascism ends over time. These units are known in the names as:

1. BJP - Bhartiya Janata Party

2. BKS - Bhartiya Kisan Sangh ${ }^{1}$

3. BMS - Bhartiya Mazdoor Sangh ${ }^{2}$

4. Seva Bharti ${ }^{3}$

8. VHP - Vishwa Hindu Parshad ${ }^{7}$

9. HSS - Hindu Swayamsevak Sangh ${ }^{8}$

10. SJM - Swadeshi Jagran Manch ${ }^{9}$

13. VKA - Vanavasi Kalyan Ashram ${ }^{12}$

14. MRM - Muslim Rashtriya Manch ${ }^{13}$

15. BD - Bajrang Dal ${ }^{14}$

16. AJJABP - Anusuchit Jati - Jamati

Arakshan Bachao Parishad ${ }^{15}$

${ }^{1}$ It is Indian Farmers Association.

${ }^{2}$ It is Indian Labor Association.

${ }^{3}$ This is an organization for the service of needy ones.

${ }^{4}$ It's a nation-wide organization for women.

${ }^{5}$ It is an all Indian student forum which works as a national student union.

6

${ }^{7}$ World Hindu Council

${ }^{8}$ Its an overseas wing for serving as Hindu volunteer organization

${ }^{9}$ Nativist Awakening Front
5. Rashtra Sevika Samiti ${ }^{4}$

6. ABVP - Akhil Bhartiya Vidyarthi Parshad ${ }^{5}$

7. Sikhsha Bharati ${ }^{6}$

11. SSM - Sarasvati Shishu Mandir ${ }^{10}$

12. $\mathbf{V B}-$ Vidya Bharti ${ }^{11}$

17. LUB - Laghu Udyog Bharati ${ }^{16}$

18. BVK - Bhartiya Vichara Kendra ${ }^{17}$

19. VSK - Vishwa Samvad Kendra ${ }^{18}$

\footnotetext{
${ }^{10}$ Nursery

${ }^{11}$ Educational institutions

${ }^{12}$ Ashram for welfare of tribal community

${ }^{13}$ Public policy think tank which has six centers.

${ }^{15}$ Organization for the improvement of Dalits

${ }^{16}$ It is a widespread network of small-scale industries

${ }^{17}$ A group of think tank association

${ }^{18}$ It is a wing for a mass communication nationwide with a team of IT experts.
} 


\section{Rashtriya Sikh Sangat ${ }^{19}$}

\section{VK - Vivekananda Kendra ${ }^{20}$}

These aforementioned affiliated organizations or the wings of RSS clearly reflect the stance that this nationalist paramilitary organization, Rashtriya Swayamsevak Sangh, has its influence in every walk of Indian political life like a complete government in its own which can exercise its stronghold to every tear of the society. Moreover, the incident of mob attack, as well as lynching in the name of cows as a mother, all such extremist events, are carried out by the people from these wings of Rashtriya Swayamsevak Sangh. For example, the JNU incident was carried out by ABVP, which is the students' council at the national level (Ayyub, 2020). Besides this, the irrational reaction from the police to such mobs and lynch is always absent or sometimes goes with any lame excuse which clarifies the fact that such acts of saffron terror are not conducted as an independent move from any state - against the group but are always having backhand from the state apparatus.

There are many episodes of saffron terror which was practiced on the Muslim community mainly, and still, the Hindutva phenomenon is making them their target of tyranny. It is said by one of the Indian newspapers that it seems India is sleepwalking towards the holocaust of Muslims in the same way as did the Hitler towards Jews. There were various worth mentioning deals behind this claim. The Muslims of India have been going through the process of the same kind of denunciation and condemnation as Jews in Germany were used to under the flag of the Nazis regime. This exclusion can be meant the same in the way the Muslims in India are excluded from the mainstream Indian society for the fact like bigotry, faith-based racial profiling, media representation in the negative forms. Same in the way, in Nazi Germany, the Jews were represented as the bad boys or the bad guys in their movies. Similarly, the Muslims are also portrayed as gangsters, looters, kidnapers, mafias, antinational, terrorists, and so forth,

\footnotetext{
${ }^{19}$ A nation-wide wing to extend knowledge regarding Sikhism holy scripture, Gurbani.

Delhi as a public policy think tank with six centers of study

${ }^{20}$ promotion of Swami Vivekananda's ideas with

Vivekananda International Foundation in New
} 
which rationally hits to mind that there are inequality and differentiation based on the religious foundations (Raja, 2020).

It is not only limited to Muslims but also to the lower caste Dalits who are untouchable Hindu community in India. These people make up about more than 300 million populaces of India, but the list of brutality is outnumbering it (Network, 2019). Dalit is a segment that is, as mentioned earlier, thought to be the low or downgraded class of society, and there are many events where Dalits were forced to bear the despotism of the dominant Hindu class. Even the occurrences are present where these people are forced to drink the urine of the dominant Hindus. Additionally, the story of repression does not stop here, and little boys were killed because of mere plucking flowers (Mayell, 2020). National Geographic also reported that Dalit is also accused of being witches and then were made to parade around without clothes (ibid.).

It is also found that it is this downtrodden class of India, among which ninety percent are living below the poverty line, and ninety-five percent are illiterate as per the statistical data presented in the. They are given due share and neither the economy nor in the social welfare despite the official claims of the ruling party and dominant class groups that they have separate quota for Dalits in jobs. Here employment is a far-flung a topic to consider when the events like Dalits are not even allowed to drink water from the same well, cannot drink tea in the same cups at tea stalls on which upper-caste Hindu enjoy their tea. Additionally, it is not stopped here, Dalits cannot keep wearing their shoes in the presence of an upper-class Hindu, nr even allowed to attend the same temple where upper-caste Hindu goes.

For Muslims, this saffron terror from BJP and RSS volunteers is even more horrific. Muslims are kept imprisoned in detention camps, police raids on Muslim praying places as well as at the Jamia universities. All these acts are done intentionally, which leads to beating up Muslims in public, demolishing their houses all in the name of mother cow protection. One of the articles says that, according to Dr. Gregory, "foreseen events of mass extermination is on the way in India under Modi regime as its no surprise because he (Modi)has already led genocidal activity against Muslims in Gujrat. So, it is definitely underway (Raja, 2020).” 
Here it can be seen quite evidently that the fascist trait of dominant and suppressed groups fulfilled when to comes to with Muslims of the Dalits in Indian republic which is slowly but steadily losing its secularism in the name of not Hinduism but Hindutva which only seek truest race as Hindus with dominant caste.

Another characteristic of fascism is the feeling of victimhood in the minds of the public. It is researched that in India, the thought which is prevalent among the Hindu society is that Hindus have been the victims of Muslim machination since past. Hindutva ideologues insist that Hindus constitutes a downtrodden group, their identity and tradition besmirched and even suppressed both by adherents of faiths and by the secular elites.

The last four of Stanley Jason's characteristics of fascism alludes to the obsession for plot regarding law and order, sexual anxiety regarding the weak women's power in the patriarchal Indian society. These mainstays of Fascism allude to neurosis about lawfulness (think about the attack of Muslims as fear-based oppressors or illicit foreigners); sexual uneasiness about the defenselessness of ladies in the prevailing gathering to other men (think about the free for allaround 'adoration jihad'); the thought of 'Sodom and Gomorrah', a disdain of cosmopolitan, urban elites as wanton, crossbreed and degenerate (instead of the ethical solidness of the normal resident), and, in conclusion, the case that the foe bunch is lethargic and necessities to work more enthusiastically. (The chilling German expression Arbeit Macht Frei — work will make you free-lined the entryways of the Auschwitz death camp.)

Same is Indian regime doing, setting up detention camps and already have six detention camps in operation which have given space to the Muslims mostly Bengalis who have failed to fulfill the national registry for citizen (NRC) and citizenship act (CA) demands. These Muslims to whom Indian governments have refused to accept them as their inhabitants are forced to live in these detention camps out of which one camp is the world's largest detention camp ever - clearly making Indian regime following the footsteps of fascists and Nazis regime in Germany. It is researched that there are over nineteen lac people mainly comprising Muslims who are likely to be in the detention camps as they have been unsuccessful in proving that they are nationals of India as per the requirements given by the state authorities (TIMESOFINDIA.COM , 2019). 
With minor exceptional cases, you can discover ground for practically every one of these characteristics in the ascent of Hindutva in India. From 9 to November 10, 1938, the German government urged its supporters to torch places of worship and crush up Jewish homes, shops, organizations, schools. In any event 91 Jews - and most likely some more - were executed by Nazi supporters egged on by Joseph Goebbels, the pastor for open edification and publicity, in what got known as Kristallnacht - "the Night of Broken Glass (Cockburn, 2020). " It was an unequivocal organizing post making progress toward mass destruction. And same happened on February 23, 2020, in Delhi, Hindu patriot crowds wandered the roads consuming and plundering mosques along with Muslim homes, shops, and organizations (ibid). They slaughtered or consumed alive Muslims who could not getaway, and the police generally unprotected the casualties. In any event, 37 individuals, practically all Muslims, were executed, and numerous others pounded the life out of a large portion of a two-year-old infant was stripped by a posse to check whether he was circumcised - as Muslims generally seems to be, yet Hindus are definitely not. Some Muslim ladies claimed to be Hindus so as to getaway (Cockburn, 2020).

Government complicity was not as immediate as in Germany 82 years sooner, yet activists of the decision Bhartiya Janata Party (BJP), drove by Indian head administrator Narendra Modi, were accounted for as being in the bleeding edge of the assaults on Muslims. A video was distributed demonstrating Muslim men, shrouded in blood from beatings, being compelled to lie on the ground by cops and constrained to sing devoted melodies. Modi said nothing for a few days and afterward made a dubious intrigue for "harmony and fraternity (ibid.)."

The administration's genuine demeanor towards the viciousness was indicated when it, in a flash, moved an appointed authority reproachful of its activities during the mobs. Judge Murali Dhar of the Delhi High Court was hearing petitions about the savagery when he said that the court could not permit "another 1984" to occur, alluding to the slaughtering of 3,000 Sikhs by hordes in Delhi in that year after the death of previous head administrator Indira Gandhi by her Sikh guardians (Op cit.). He said the legislature ought to give the safe house to the individuals who had been compelled to escape and addressed if the police were appropriately recording casualties' grievances. 
The administration says that Judge Murali Dhar's exchange had just been reported and asserts that its quick usage of the move had nothing to do with his comments. Regularly the claim is accepted by the informer, and, on various occasions, it is basically a term of misuse. However, Modi and the BJP show up nearer than other conservative systems to conventional despotism in their extraordinary patriotism and availability to utilize savagery. At the focal point of their plan is their image of Hindu patriotism and a persistent offer to underestimate or remove India's 200 million Muslims (Cockburn, 2020).

Regularly they charge accepted by the informer, and, on various occasions, it is basically a term of misuse. However, Modi and the BJP show up nearer than other conservative systems to conventional dictatorship in their extraordinary patriotism and preparation to utilize brutality. At the focal point of their plan is their image of Hindu patriotism and a steady offer to underestimate or expel India's 200 million Muslims.

The remainder of the world has been delayed getting a handle on the gravity of what is going on in India in light of the fact that the Modi government has made light of its task to move India from its past status as a pluralistic mainstream state. The sheer number of individuals contrarily influenced by this change is immense: in the event that the Muslim minority in India was a different nation, at that point, it would be the eighth biggest state on the planet by the populace.

The brutality in Delhi in year 2020 comes from the dread and contempt created by the administration coordinated pincer development against Muslims in India. One pincer is looking like the Citizenship Amendment Act (CAA), under which non-Muslim vagrants can quickly increase Indian citizenship; however, Muslims cannot (ibid). Significantly additionally undermining is the National Register of Citizens (NRC), which is probably going to deny numerous Indian Muslims of their citizenship. It was the peaceful fights and shows contradicting these measures that incited the Hindu patriot hordes into arranging what was near a slaughter not long ago. 
Exactly how far Modi and the BJP will go in their enemy of Muslim battle is as of now in proof in Jammu and Kashmir, the one Indian state with a Muslim lion's share. It was immediately deprived of its independence last August and has been secured from that point onward (Cockburn, 2020).. Mass detainments and torment are the standards as per a couple of witnesses ready to report what they have seen.

For 150 days after the legislature disavowed Jammu and Kashmir's uncommon status, the web was cut off, and it has just been reestablished to a restricted degree since January. The security powers confine whom they need and upset relatives grumble that they cannot discover their family members or that they are too poor even to consider visiting them in detainment facilities that might be 800 miles away (Cockburn, 2020).

The burnings and killings in Delhi this week are very much broadcasted, yet respected with a specific resistance globally: Modi can exchange off India's notoriety for being a broken-down majority rule government and an inclination that "collective viciousness" is customary in India, similar to tropical storms in Florida or quakes in Japan, and no one is true to a fault.

There has been an empowering, however, savagely stifled rush of restriction in India to the debasement of its non-partisan conventions. The threat here - and the crowds in Delhi might be an indication of this - is that Modi and his legislature will react to these fights by playing the Hindu patriot card considerably more emphatically.

Managing remote analysis, the legislature may state that, paying little mind to its local political program, it is supercharging monetary development, and this reasons its different failings. Dictator systems, with command over the greater part of their own media, frequently make such cases and, when financial insights show the inverse, they basically counterfeit another arrangement of figures. An ongoing investigation of the Indian economy noticed that, while generally speaking, financial development had apparently risen unequivocally, the development in speculation, benefits, charge incomes, imports, trades, modern yield, and credit had all debilitated as of late. 
In one regard, Modi is in a more grounded position than Germany after Kristallnacht. President Roosevelt reacted with an announcement censuring discrimination against Jews and savagery in Germany and immediately pulled back the US minister. President Trump, on a two-day visit to India during a period that Muslims were being pursued down and killed a couple of miles from where he was sitting, said he was fulfilled that Modi was buckling down "extremely hard" to set up the strict opportunity.

India, with BJP government and RSS ethnic purging thought processes, have not just attempted to monger war outside their fringes yet additionally inside their own nation. The RSS plan rotates around blazes of anguish and a complex of predominance. Their unsavory thought processes can be plainly comprehended by the total check in time that was not forced because of dread of the spread of COVID-19, but since of their goal to smother the voices of Kashmiris. That lockdown was a lot of more terrible than the COVID-19 lockdown faced by the world today. No entrance to any national or global media nor organize inclusion was open. In a few inside meetings from neighborhood individuals, it was uncovered that individuals had to close their shops as well as clear the region. Nobody to date knows, what number of lives are lost around there by severe killings, craving, or pain. Human rights associations have hugely neglected to give an option to live to those individuals. Another scene, further portraying the sickening thought processes of BJP government was going of CAA in December 2019, explaining their disdain towards outsiders, particularly Muslims. Additionally, the denial of Article 35 An and Article 370 for denying Kashmiris of their own one of a kind presences. Muslims in India are by and by living in a condition of dread and are savagely pounded the life out of even by not just Hindu radicals in addition to the police authorities (The Hindu, 2019).

With the episode of the ongoing coronavirus, the world appeared to join together, against a shared adversary. Numerous countries joined their hands and caused colossally to conquer the emergencies. Then again, India depicted a totally unique picture. Where the global clinical specialists discover bats or different creatures for the reason for this pandemic. Indians decided to be driven by the RSS intentions and reprimanded Muslims for the spread of the infection. Muslims in India are confronting outrageous predisposition on strict grounds (Ansari, 2020). 
The other points on which the fascism can be proven in India are victimhood, law, and order control, hierarchical situation, sexual anxiety. And these points can be evident in the following arguments.

Indian regime is following fascist characteristics in the name of propagating sexual anxiety among its masses. The Hindu leaders are readily claiming hat these are the Muslims who has been long into the rapes of Hindu girls and out of total a percentage of rape cases, ninety six percent counts the Muslim rapist (Kudrati, 2019). Another such tweet was also made by the Prof Hari $\mathrm{Om}^{21}$ which was provoking the Indians against Muslims by saying, "Hindu Rashtra is a must thing if we want Hindus, Bharath, Hindutva and Hindu girls to survive because the number of rape cases committed between 2016 to 2018 ranges to 84374 and from this large number only 3374 are the Hindus and others while 81000 are Muslim rapists ${ }^{22}$."

However, the source cited by him and various other people regarding these facts are reported later to be a fake news which also another characteristic present in a fascist regime. So, polarization of the community, victimhood, unreality, propaganda, sexual anxiety, demagoguery, and anti intellectualism all these pillars of fascism fall true in India. And that NRC issue also related to the above fascist pillars.

A study was carried out on inverted information and fake news in India by researchers from the University of Michigan, published on April 18, 2020, has indicated an ascent in the quantity of exposed fake stories, especially after the declaration of Janata check in time by Prime Minister Narendra Modi on March 22, 2020, and the countrywide lockdown two days after the fact, to contain the spread of COVID-19. From only two in the third seven day stretch of January 2020, the occurrences of exposed deception rose to 60 by the principal seven day stretch of April 2020,

\footnotetext{
${ }^{21}$ Prof Hari Om, previous Dean of Faculty of Social Sciences, Professor Maharaja Gulab Singh Chair University of Jammu and part Indian Council of Historical Research has left the essential enrollment of the Congress party claiming that the gathering had capitulated to the delicate secessionism and communalism and had just ended up being an expansion of the National Conference.

${ }^{22}$ The tweet's archive can be cross checked from here, http://archive.is/yM3LD.
} 
as per the study. In spite of the fact that phony stories around a remedy for COVID-19 reduced in this period, bogus cases that influenced individuals genuinely expanded, the study found.

The study utilized 243 one of a kind cases of inverted information derived from an archived document kept up by Tattle Civic Technology (a Delhi-based news venture that plans to make exact data increasingly open to cell phone users). The document speaks to all the tales that have been exposed by six truth checkers- - AltNews, BOOMlive, Factly, IndiaToday Fact Check, Quint Webqoof, and NewsMobile Fact Checker- - confirmed by International Fact-Checkers Network (IFCN) between January 23 and April 12, 2020. Although the reports accusing the fact that Muslims are injected for corona virus are also in the air fuming up the atmosphere with discrimination propaganda and racial anxiety (Akbar, Kukreti, Sagarika, \& Pal, 2020).

The idea for the war mongering nature of India and its ruling contemporary regime can be taken int account y considering mere the speeches of prime minister Narender Modi and defense minister as well as the army general of India. For an instance, on twenty first of April 2019, the prime minister of India Narendra Modi deterred verbally in his speed in a rally at Rajasthan in the words that the nuclear muscles of India are not been kept for Diwali. 


\section{CHAPTER 4: REGIONAL IMPLICATIONS OF INDIAN FASCIST MOVEMENT \& FORESEEN POSSIBLE DYNAMICS}

Mr. Modi rose to power demonizing ethnic-religious minorities, immigrants, and the established media, and boasting about the size of a body part (Duvvuru, 2019). The administration's Hindu nationalist and against Muslim strategies have ignited fights in India as well as abroad. The administration crackdown on the fights in India raised further clamors. The United States, the European Union, and the United Nations secretariat have all approached the Modi government to scrap its unfair arrangements. Following the COVID-19 flare-up, Indian administration has not plummeted its actions of tyranny on the target Muslim group whether inside India or into the disputed territory of Kashmir and Ladakh.

Prior, Indian ambassadors attempted to get over global worry as "exclusive matter," and the BJP propelled an open crusade to counter endeavors to "delude the country." Prime Minister Modi has demanded that these approaches are not oppressive, saying, "Muslims are a chunk of our country, and they enjoy equal rights and obligations as others." However, he has done little to start a discourse with the nonconformists, get control over his rally personnel and supporters who routinely attack Muslims, or press state governments to indict those liable for mistreats.

Pakistan and other neighboring states are disturbed of Indian maltreatments' actions which are th result of its ruling regime ideology, Hindutva. Leaders in Pakistan have repeatedly pointed out the ill effects f Hindutva pursuance on the region and specifically on the Muslims who are in minority to Hindus. At various levels, this voice against BJP-RSS synced ideology has been raised by Pakistan's ruling prime minister. Imran khan has showed his concerns over regional dynamics shift because of Indian brutality over Muslims. He has made united nations and its member states clear of Indian Hindutva's intentional moves which he subjected as the fascist moves intending to do genocide of Muslims in India. 
According to The Frontier Post in Implementing Rss Evil Ideology, "Despite the total information blackout, TV footages are coming out of Kashmir that showed how thousand of Kashmiris defied and broke the curfew restrictions on Friday and protested on roads and streets of Srinagar. These footages were aired on international TV outlets including BBC and Aljazeera. The Indian forces had opened direct firing on the protestors and tear-gassed them, injuring a number of people. RSS political philosophy is based on the principles of Hindutva that advocates the supremacy of a Hindu state and nurturing hardcore Hindu principles. It is an oppressive and extremist ideology of imposing supremacy of high cast controlled Hinduism over the millions followers of other religions including Islam, Christianity, Buddhism, and Zoroastrianism. It is even a threat to Sikhism founded by Guru Nanak. Ideologically, it is identical to Shudhi Movement of pre-partition Subcontinent which had been started by Arya Samaj to forcefully bring back the people who converted from the cast ridden Hinduism to Islam and Christianity. In other words, the RSS ideology not only poses grave threat to the survival of Muslims of India alone but also followers of Christianity, Buddhism, Zoroastrianism and Sikhism. The BJP government policy will certainly undermine the secular provisions of Indian Constitution. That is why former Prime Minister of India Dr. Manmohan Singh and other towering political figures of Indian Congress Party have criticized the abrogation of special constitutional status of Jammu and Kashmir which was guaranteed in Articles 370 and 35 A (The Frontier Post, 2019).”

Muslims, specifically, have raised worries about the National Register of Citizens in light of the issues that have just happened in the northeastern territory of Assam, which is the main state to have finished such a check procedure. It prohibited almost 20,00,000 individuals, the greater part of them ethnic Bengalis, whom the experts blame for entering India illicitly from neighboring Bangladesh.

On 2019, in "President Alvi Asks to Pay Attention to RSS, BJP Agenda" in The Nation, President of Pakistan Dr. Arif Alvi wrote, “In Modi’s Gujarat, Hitler is a textbook hero. RSS/BJP agenda takes inspiration from Hitler and the Ideology of Nazism. The World should pay attention http://toi.in/YZR0ia/a24gk via@timesofindia.” 
According to Imran Khan Nazi; Prime Minister of Pakistan in "'Rss Ideology of Hindu Supremacy Will Lead to Suppression of Muslims in India and to Targeting of Pakistan'," (2019) in Daily Dawn, "The curfew, crackdown and impending genocide of Kashmiris in Indianoccupied Kashmir is unfolding exactly according to RSS ideology [that is] inspired by Nazi ideology. "They [Indian state forces] will now crack down even harder on the Kashmiri people. They will try to suppress the Kashmiri resistance with brute force. I fear that they may initiate ethnic cleansing in Kashmir to wipe out the local population. With an approach of this nature, incidents like Pulwama are bound to happen again. I can already predict this will happen," he had added. "Question is: will the world watch and appease as they did Hitler at Munich? They are changing [the] demography of Kashmir through ethnic cleansing. "RSS ideology of Hindu supremacy, like the Nazi Aryan supremacy, will not stop in IOK (Indian Occupied Kashmir); instead it will lead to suppression of Muslims in India and eventually lead to targeting Pakistan" He referred this to as a version of Lebensraum practiced by Hitler (Dawn.com, 2019).

\section{PAKISTANI \& INTERNATIONAL STANCE}

On 2019, in "PR No. 31; Kashmir Solidarity Day Message by Patron-in-chief Youth Forum for Kashmir/federal Minister/chairman Privatization: Islamabad” in Pid.gov.pk, Mohammed Mian Soomro wrote, "Indian Occupied Kashmir is stripped off its special status after seven decades through revocation of Article-370. Ultra-nationalists/right-wing is bent on suppressing the voices of Kashmiris. The introduction of the Citizen Amendment Bill (CAB) is a death blow to the socalled Indian ideology of pluralism and secularism. Pakistan vociferously voices its concerns over the worst ever human rights violations and abuse of power by the Indian armed forces against Kashmiris at Modi's diktats. We urge the international community to support the right of self-determination for the people of Indian Occupied Kashmir according to the UNSC resolutions. Prime Minister Imran Khan has fought Kashmir Cause with new spirit at all international forums; we will continue to support the resistance of Kashmiris against Indian oppression (Soomro, 2019).” 
PM Imran khan speech on Kashmir day February 05, 2020-in Muzaffarabad AJK also has euphemistically indicating towards the irrational policy of fascist trend being ignited under BJP rule on India with RSS mandate to be followed and changing demographics of Kashmir from Muslim majority populace to Muslim minority or Hindu majority population. His actual address was in the following words (Friedman, 2017):

The geopolitical perspective of BJP-RSS Hindutva doctrine has been widely neglected and overlooked by many scholars and the experts. However, its not the case, it is actually china towards which India has an eye of competition in Asian continent. And achieving this regional hegemony is one of the dreams to become true.

"The classical version of the territorial notion aimed for the physical assimilation of Bangladesh, Pakistan, Sri Lanka, Bangladesh, Nepal and Bhutan, viewed as an integral part of the Indian 'fatherland.' The founders of the Hindutva ideology asserted that the Indian natural borders stretched from the Indus to the Eastern Sea, and from the Himalayas to Kanyakumari. Since the physical integration of South Asian states into the Indian Union sounds like an unrealistic proposition, the BJP has devised a softer and more plausible version of the geopolitical agenda of the Hindutva ideology (Munawar, 2019). Modi seeks to implement the 'neo-Akhund Bharat strategy' that is premised on the idea of creating a 'United South Asian Strategic Space' as an exclusive sphere of Indian influence. In an interview to Al Jazeera in December 2015, Ram Madhav, BJP general secretary, said that they hoped to create a 'Great India' that would include India, Bangladesh and Pakistan. The improvised Akhund Bharat blueprint of the BJP carries the seeds of heightened tension in the Sino-India relations in the long run because the strategy entails countermeasures to the growing Chinese geo-economic inroads and geopolitical influence in the region, and that is of vital importance in the geopolitical calculus of the Hindutva doctrine," argued Dr. Mahar Munawar in "China’s Tryst with Hindutva's Geopolitical Agenda" in Daily Times on 2019. 
The vigorous policy attitude towards Beijing is evident the gauge of the unfolding paradigm shift in New Delhi's conventional approach towards its Asian arch-competitor cum rival.

Moreover, it can be analyzed from the above facts and statements by the heads of different states that the change in ideological phenomenon of Indian Policy is not only affecting the domestic front but also rising discords on its borders especially in the disputed territory which by no means can be occupied without the UN as a mediator but it is the instilled jugs of dissolute fascist mindsets poured in the public by BJP in order to get elected on massive scale which has arisen and will arise more thoughts linking to the fact that Indian political elite is thinking their way ahead the fascist inspirations and believing in ethnic purification besides superior descendent of Aryan race concept. 


\section{CHAPTER 5: CLOSING REMARKS \& DEDICATED WAY FORWARDS}

After discussing the abovementioned facts and figures and doing the analysis of the qualitative data given above, it cannot be deduced that both dissolute fascism and the ultra-nationalistic surge is accrued in India but its negative nationalism which is paving its way towards dissolute fascist trends. Although, the possible circumstances are present are that these situations may end up in the stabilized authoritarian and fascist regime which will only go for Hinduism growth or Hindu dominated society as soon as developing the Monolithic India. It can be observed from the given chapters of this thesis that the state of India is all settling its stage on the to characteristics of a fascist regime or a fascist nation which was classified as the dissolute fascist agenda. For this purpose, the situation should be dealt with cohesive efforts from all the powers around the world to command India from its furious plans of conducting Hindutva doctrine in Asian region.

Of course, calling modern political leaders and parties fascist, draws inevitable pushback; it trivializes the atrocities of the 20th century to compare the likes of Hitler to a self-aggrandizing demagogue like Trump. Instead, it is more useful to recognize that societies at a broader level are complicit in the ascendency of hateful, domineering politics. If the masses of a nation are not vigilant against the demonization of people in their midst, if they let their history be reduced to simple sagas of triumph or woe, and if they let blundering emotion rule over calm and scrutiny, then they court fascist disaster.

The agenda on the table is to turn the state into a monolingual, monolithic and authoritarian state rules by one party only which in this case of India is BJP. If one will try to sum up comes with thoughts that the Indian society; although not has yet declared to be turning into fascist substance but can be vividly examined from the certain aspects discussed in this research work that the fascist forces like the Sangh Parivar administrating Rashtriya Swayamsevak Sangh and shooting out as Bhartiya janta party in rule falls soundly upon those features of fascist ideology. And, it can be unbiasedly stated that these characteristics can be seen growing more concentrated with the passage of time and the movement has taken pace ahead in implementing all those fascist 
ideas which were covertly defined under the umbrella of Hindutva alias and practically imposed by RSS cum BJP alliance with hundreds of offshoot small organizations like Bajrang dal etc.

History of fascist regimes tell that Modi is rehashing in Jammu and Kashmir what Hitler has finished with Jews in Germany. Generally, this question is a two headed beast, ethnic fixation, and ethnic purifying. By and large, all such organizations had completed the previously mentioned vicious strategies so as to execute their destructive plans, along these lines Narendra Modi and his Pierre Jamaels (fascists) are not a special case. Teacher Achin Vanaik of Jawaharlal University of Delhi has been continually disturbing the populace about Hindutva dictatorship since 1997 by calling it Saffron terror and fascist warriors (Ahmad, 2019). On the off chance that the worldwide network is as yet unfit to make a move, we are taking a gander at a mass annihilation, and potentially the physical eradication all things considered.

The 2019 Citizenship Amendment Act abuses India's universal commitments to forestall hardship of citizenship based on race, shading, plummet, or national or ethnic inception as found in the International Covenant on Civil and Political Rights and other human rights arrangements that India has endorsed. The 1992 Declaration on the Rights of Persons Belonging to National or Ethnic, Religious and Linguistic Minorities approaches governments to secure the presence and personality of strict minorities inside their regions and to receive the fitting measures to accomplish this end. Governments are committed to guarantee that individuals having a place with minority gatherings, including strict minorities, may practice their human rights without segregation and in full fairness under the steady gaze of the law. Governments likewise have a commitment to guarantee sexual orientation fairness. To the degree that the procedure has an excessively unsafe effect on the citizenship privileges of ladies and young ladies, it additionally disregards the Convention on the Elimination of All Forms of Discrimination against Women (Human Rights Watch, 2020).

Indian administration has attempted to legitimize the law, saying it tries to give asylum to strict minorities abroad escaping abuse. In any case, that guarantee is given a false representation of by the avoidance of numerous other weak gatherings who have looked for shelter in India, for example, minority Tamils from Sri Lanka and ethnic Nepalis from Bhutan. It additionally 
adequately bars other oppressed Muslim minorities like the Hazaras from Afghanistan, the Shia and Ahmadiyya from Pakistan, and the Rohingya from Myanmar.

The impact of coronavirus as per the socio-economic breakdown would result in the increasing fascist marketing trend of protectionism. The regional implications of Indian fascist movement can be seen vividly in the region specially when it comes to the traits like war mongering nature, the trade and tariffs state imposed by it, its Hindutva ideology spread in disputed area of Kashmir valley, all these things have heavy influence over regional dynamics.

India's administering elites have severely neglected to incorporate Muslims into its state and society. They have by and large oppressed Muslims to political estrangement, financial hardship, strict segregation, and social underestimation in the post autonomy period. The ascent of common legislative issues since ahead of schedule 1980s, and consistently becoming stronger of fanatic Hindu gatherings have additionally pushed Indian Muslims to the less than desirable end. The activists of radical Hindu gatherings have over and again focused on lives, property, respect, and strict spots of Muslims and sporadically scared them to constrained change. On occasion, the Indian specialists and media had depicted Muslims as culprits of psychological oppression when they were really its casualties. Indian decision-making elites, ideological groups and media have severely neglected to characterize the job and position of Muslims in the nation. The Muslims have commonly battled hard to demonstrate that they were steadfast Indians by all methods yet Indian government, ideological groups, and media for the most part suspect them.

The Hindu patriots forced on Indian Muslims the physical and mental segment which filled in as an outward power for South Asian regionalism. The assaults on the lives, property, respect, and strict spots of Muslims also, annihilating of mosques and altars sent negative message abroad, especially the Muslims living in neighboring nations. The disappointment of India's administering elites to regard the religion-social character of Muslims and ensure their political advantages and monetary rights in the post - freedom period strengthened the feelings of trepidation and worries of Muslims living in other South Asian nations and subsequently filled in as a negative power for South Asian regionalism. 
Thus, it can be concluded from the above study that the acts which proves fascist rise in India such that disdain for human rights, corporate power protection, raging sexism, obsession with national security cult, religion and government are entwined, identification of enemies as a coalescing cause, fruiting and intense corruption, fraudulent elections, suppression of labor power, military admiration, mania with crime and punishment hysteria, disparagement of intellect and above all influential and up surging ultra nationalism, all these can be found as increasing instances in Indian regime. Human rights, media suppression, military obsession victimhood, ultra religious inclinations all can be seen practically not only inside India but also being practiced over IHK and Ladakh.

Now, the point comes how to fight against and get rid of fascist mindset and its prevailing practices in India. Getting rid sounds, a way too hard word in practice. Although we can try plummeting the effect of fascist tendencies in a state by numerous ways. First of all, the ordinary people who are the main target of such fascist regimes should be made well aware about the tactics which any state being fascist implement over its people. There are distinct signs which leaders leave in their speeches especially during the times of election campaigns as it was the NRC act for which BJP government vowed to implement completely in the current rule and so as it did which has brought bad impacts over the national population and has caused a significant divide among the majority and minority groups in India and it was not only about majority and minority but it has created a hatred against a specific community in India i.e. Muslims. Although it served a purpose for unifying cause for Hindus on the bass of Hindutva ideology but this ultrasonic nationalist surge if I name not as bad nationalism is overlaying its ways towards dissolute fascist trend strongly and intensely.

It is said in 1775, in Samueljohnson.com, Samuel Johnson wrote, "The last refugee to scoundrel is patriotism." And so, I can foresee in Indian political dynamics that to get rid of the Muslims, Indian administration and the leaders in the past utilized a tool of chauvinism which turned into ultra-negative patriotism giving a factual resemblance with Hitler khaki shirts where only difference is RSS has khaki pants paramilitary wing. So, I can close this research work with 
remarks that obvious shifts towards dissolute fascism can be seen with gradual progress from negative nationalism.

\section{REFERENCES}

22. Ahmad, K. (2019, September 22). Telltale Signs of Fascism in Modi's India. Retrieved July 23, 2020, from https://cscr.pk/explore/themes/politicsgovernance/telltale-signs-of-fascism-in-modis-india/

23. Ahmed, H. (2014). What is BJP's ideology?. Retrieved 9 July 2020, from https://www.epw.in/blog/hilal-ahmed/what-bjps-ideology.html

24. Ajj Tak. (2020). Sangham: Birth and growth of Rashtriya Swayamsevak Sangh $(R S S)$ [Video]. Retrieved from https://www.youtube.com/watch?v=Cxz-lBqfVXc

25. Akbar, S. Z., Kukreti, D., Sagarika,, S., \& Pal, J. (2020, April 16). Temporal Patterns in COVID-19 misinformation in India. Retrieved July 17, 2020, from http://joyojeet.people.si.umich.edu/temporal-patterns-in-covid-19misinformation-in-india/

26. Alder, K. (2020). The Origins of Today's Hindu Nationalism. Retrieved 9 July 2020, from https://www.usnews.com/news/best-countries/articles/2016-03-02/theorigins-of-todays-hindu-nationalism

27. Ansari, B. (2020, May 13). India's Warmongering Attitude despite Global Pandemic. Retrieved July 17, 2020, from https://moderndiplomacy.eu/2020/05/14/indias-warmongering-attitude-despiteglobal-pandemic/

28. Antliff, M. (2012). Fascism and Art History: A Paradigm Shift. Retrieved 10 17, 2019, from https://brill.com/view/journals/fasc/1/1/article-p53_3.xml?lang=en 
29. Ayyub, R. (2020, January 08). What Happened at JNU During the Attack. Retrieved July 22, 2020, from https://time.com/5760597/what-happened-duringjnu-attack-india/

30. Banaji, J. (2013). Trajectories of Fascism: Extreme-Right Movements in India and Elsewhere. Retrieved 10 17, 2019, from http://eprints.soas.ac.uk/16825/1/jamia lecture (fascism).pdf

31. Banaji, S. (2018). Vigilante Publics: Orientalism, Modernity and Hindutva Fascism in India. Javnost-the Public, 25(4), 333-350. Retrieved 10 17, 2019, from https://tandfonline.com/doi/full/10.1080/13183222.2018.1463349

32. Chattopadhyay, K. (2009). India, Hindutva, and Fascist Mobilizations, 19892002. The International Encyclopedia of Revolution and Protest, 1-4. doi:10.1002/9781405198073.wbierp0744

33. Cockburn, P. (2020, February 28). Opinion: While Muslims are being murdered in India, the rest of the world is too slow to condemn. Retrieved July 22, 2020, from https://www.independent.co.uk/voices/delhi-riots-news-narendra-Modimuslims-hindus-jammu-kashmir-trump-a9365376.html

34. Dawn.com. (2019, August 11). 'RSS ideology of Hindu supremacy will lead to suppression of Muslims in India and to targeting of Pakistan'. DAWN.COM. https://www.dawn.com/news/1499293.

35. Desai, R. (2016). Hindutva and Fascism. Retrieved 9 July 2020, from https://www.academia.edu/30813538/Hindutva_and_Fascism

36. Desai, R. (n.d.). A latter day fascism. Economic and Political Weekly, 49(35), 4858. Retrieved 10 17, 2019, from http://www.epw.in/journal/2014/35/specialarticles/latter-day-fascism.html 
37. Desk, I. (2019, August 29). BJP inducts 7 crore new members, creates membership drive record. Retrieved July 16, 2020, from https://www.indiatoday.in/india/story/bjp-inducts-7-crore-new-members-createsmembership-drive-record-1593164-2019-08-29

38. Duvvuru, K. (2019, July 30). Is India displaying signs of neo-fascism? Retrieved July 22, 2020, from https://mronline.org/2019/07/31/is-india-displaying-signs-ofneo-fascism/

39. Eatwell, R. (2003). Reflections on Fascism and Religion. Totalitarian Movements and Political Religions, 4(3), 145-166. Retrieved 10 17, 2019, from https://tandfonline.com/doi/full/10.1080/14690760412331329991

40. Farooq, G. (2018). Politics of Fake News: How WhatsApp Became a Potent Propaganda Tool in India. Media Watch, 9(1), 106-117. doi:10.15655/mw/2018/v9i1/49279

41. Franck, L. R. (1935). FASCISM AND THE CORPORATE STATE. The Political Quarterly, 6(3), 355-368. Retrieved 10 17, 2019, from http://onlinelibrary.wiley.com/doi/10.1111/j.1467-923x.1935.tb01262.x/abstract

42. Friedman, G. (2017). Nationalism Is Rising, Not Fascism. Retrieved 9 July 2020, from https://www.huffpost.com/entry/nationalism-is-rising-not_b_10281138

43. Frontier Post, T. (2019, August 14). Implementing RSS evil ideology. Retrieved July 22, 2020, from https://thefrontierpost.com/implementing-rss-evil-ideology/.

44. Fundamentalism - Sikh fundamentalism. (2020). Retrieved 9 July 2020, from https://www.britannica.com/topic/fundamentalism/Sikhfundamentalism\#ref252670

45. Golwalkar, M. S. (1947). We or Our Nationhood Defined. Nagpur City, India: Kale. 
46. Goodfellow, S. H. (2013). Fascism as a Transnational Movement: The Case of Inter-War Alsace. Contemporary European History, 22(01), 87-106. Retrieved 10 17, 2019, from https://cambridge.org/core/journals/contemporary-europeanhistory/article/fascism-as-a-transnational-movement-the-case-of-interwaralsace/ac8b472b62511cc03a346a5aed2c344e

47. Gregor, A. J., \& Chang, M. H. (1979). Nazionalfascismo and the Revolutionary Nationalism of Sun Yat-sen. The Journal of Asian Studies, 39(01), 21-37. Retrieved 10 17, 2019, from https://cambridge.org/core/journals/journal-of-asianstudies/article/nazionalfascismo-and-the-revolutionary-nationalism-of-sunyatsen/ca75402abf3b43c8005eae9291080e8b

48. Griffin, R. (1995). Fascism. Oxford University Press. Retrieved 10 17, 2019, from https://books.google.com/books?id=3ssUAQAAIAAJ

49. Heartfield, J. (2007). Face of Fascism. Retrieved 10 17, 2019, from https://dome.mit.edu/handle/1721.3/19856

50. Hindu Nationalist's Historical Links to Nazism and Fascism. (n.d.). Retrieved 10 17, 2019, from https://www.ibtimes.com/hindu-nationalists-historical-linksnazism-fascism-214222

51. Implementing RSS evil ideology - The Frontier Post. (2019). Retrieved 9 July 2020, from https://thefrontierpost.com/implementing-rss-evil-ideology/

52. Indian society is the very center of Fascism: Sunny M. Kapicadu. (n.d.). Retrieved 1017,2019 , fromhttp://roundtableindia.co.in/index.php?option=com_content\&view=article \&i d=8731:if-you-say-it-s-Modi-who-brought-fascism-to-india-i-would-say-that-s-alie\&catid=119\&Itemid $=132$

53. Jal, M. (n.d.). Rethinking Secularism in India in the Age of Triumphant Fascism. Critique, 43(3-4), 523-524. Retrieved 10 17, 2019 
54. Kohn, H. (n.d.). Nationalism. Encyclopedia Britannica. Retrieved 1 13, 2020, from https://www.britannica.com/topic/nationalism

55. Kudrati, M. (2019, December 16). Viral Post Claiming 96\% Of Rape Offenders Are Muslims Is False. Retrieved July 16, 2020, from https://www.boomlive.in/fake-news/viral-post-claiming-96-of-rape-offenders-aremuslims-is-false-6293

56. Mayell, H. (2020, June 04). India's "Untouchables" Face Violence, Discrimination. Retrieved July 22, 2020, from https://www.nationalgeographic.com/news/2003/6/indias-untouchables-faceviolence-discrimination/

57. Miscevic, N. (n.d.). Nationalism (Stanford Encyclopedia of Philosophy). Stanford University. Retrieved 1 12, 2020, from http://plato.stanford.edu/entries/nationalism/

58. Mohammed Mian Soomro. (2020). PR No. 31 Kashmir Solidarity Day Message By Patron-in-Chief Youth Forum for Kashmir/Federal Minister/Chairman Privatization: Islamabad.. Retrieved from http://pid.gov.pk/site/press_detail/12947

59. Mommsen, H. (2001). National Socialism and Fascism. Retrieved 10 17, 2019, from https://sciencedirect.com/science/article/pii/b008043076702698x

60. Munawar, M. (2019, May 30). China's tryst with Hindutva's geopolitical agenda. Daily Times. https://dailytimes.com.pk/403818/chinas-tryst-with-hindutvasgeopolitical-agenda/.

61. Munson, H. (2019, November 26). Sikh fundamentalism. Retrieved July 16, 2020, from https://www.britannica.com/topic/fundamentalism/Sikh-fundamentalism 
62. Nandy, A. (1976). Adorno in India: Revisiting the psychology of Fascism. Retrieved 10 17, 2019, from http://psycnet.apa.org/psycinfo/1977-29404-001

63. Narayanan, D. (2019, May 26). View: What shape will the BJP-RSS dynamics take under Modi 2.0? Retrieved July 16, 2020, from https://economictimes.indiatimes.com/news/politics-and-nation/view-what-shapewill-the-bjp-rss-dynamics-take-under-modi-20/articleshow/69498073.cms?from=mdr.

64. Network, D. F. (2019, June 04). Dalit 101 - Who are the Dalits? Retrieved July 22, 2020, from https://dfnusa.org/dalit-101-who-are-the-dalits/

65. Nolzen, A. (2010). Genocide and Fascism: The Eliminationist Drive in Fascist Europe. German History, 28(1), 115-117. Retrieved 10 17, 2019, from https://academic.oup.com/gh/article/28/1/115/583276

66. NOORANI, A. G. (2019). RSS. Delhi, India: LEFTWORD Books.

67. Ohm, B. (2014). Contesting interpretational authority: Democracy and Fascism in the Indian 'empowered public'. Media international Australia, incorporating culture and policy, 152(152), 119-132. Retrieved 10 17, 2019, from https://search.informit.org/documentsummary; $\mathrm{dn}=568091844325867$;res=iellcc

68. Pandey, G. (2019, June 26). Indian MP Mahua Moitra's 'rising fascism' speech wins plaudits. Retrieved July 22, 2020, from https://www.bbc.com/news/worldasia-india-48755554

69. Panikkar, K. N. (2003). Before the night falls: Forebodings of fascism in India. Bangalore: Books for Change.

70. Passmore, K. (2014). Fascism: A very short introduction. Oxford: Oxford University Press. Retrieved 2020, from https://www.torontopubliclibrary.ca/search.jsp?Ntt=Fascism. 
71. President Alvi asks to pay attention to RSS, BJP agenda. (2019). Retrieved 9 July 2020, from https://nation.com.pk/16-Aug-2019/president-alvi-urges-world-topay-attention-to-rss-bjp-agenda

72. Puniyani, D. (2017). Fascism in India: Debating RSS-BJP politics. Delhi: Media House.

73. Raja, I. (2020, February 28). Is India sleepwalking toward a Muslim Holocaust?. Retrieved July 22, 2020, from https://www.dailysabah.com/opinion/op-ed/isindia-sleepwalking-toward-a-muslim-holocaust

74. Ranasinha, R. (2010). South Asian broadcasters in Britain and the BBC: talking to India (1941-1943). South Asian Diaspora, 2(1), 57-71. Retrieved 10 17, 2019, from https://core.ac.uk/display/29900231

75. Reich, R. (2001, December 19). Good and Bad Nationalism. Retrieved July 22, 2020, from https://prospect.org/article/good-bad-nationalism/

76. Reporter, J., Kondo, M., Cicurel, D., Grant, B., Wolfisz, F., Oryszczuk, S., . . . Flacks-Leigh, J. (2020, August 20). The Canary editor criticised over 'Arbeit Macht Frei' tweet. Retrieved September 23, 2020, from https://jewishnews.timesofisrael.com/the-canary-editor-criticised-over-arbeitmacht-frei-tweet/

77. 'RSS ideology of Hindu supremacy will lead to suppression of Muslims in India and to targeting of Pakistan'. (2019). Retrieved 9 July 2020, from https://www.dawn.com/news/1499293

78. Sam Winter-Levy, N. (2018, June 26). Analysis | When is nationalism a good thing? When it unites an ethnically diverse citizenry. Retrieved July 09, 2020, from https://www.washingtonpost.com/news/monkey-cage/wp/2018/06/26/whenis-nationalism-a-good-thing-when-it-unites-an-ethnically-diverse-citizenry/ 
79. Sangh, R. S. (2012). Vision and Mission. Retrieved July 22, 2020, from http://rss.org/Encyc/2012/10/22/rss-vision-and-mission.html

80. Sangham: Birth and growth of Rashtriya Swayamsevak Sangh (RSS) [Television series]. (2014, October 12). India: Aaj Tak. Retrieved April 10, 2020, from https://www.youtube.com/watch?v=FmoOTcWyXL0

81. Sharma, A. (2020, June 10). On the Difference Between Hinduism and Hindutva. Retrieved July 16, 2020, from https://www.asianstudies.org/publications/eaa/archives/on-the-differencebetween-hinduism-and-hindutva/

82. Shukla, R. (2020, July 07). Aspects of male sexuality enmeshing with rise of fascism in India: Tentative psychoanalytical explorations. Retrieved July 10, 2020, from https://onlinelibrary.wiley.com/doi/epdf/10.1002/aps.1658

83. SIDDIQUI, K. (2017). Hindutva, Neoliberalism and the Reinventing of India. Retrieved July 22, 2020, from http://www.kspjournals.org/index.php/JEST/article/view/1280/1325

84. Soomro, M. M. (2019, February 5). PR No. 31 Kashmir Solidarity Day Message By Patron-In-Chief Youth Forum For Kashmir/Federal Minister/Chairman Privatization: Islamabad. PID. http://pid.gov.pk/site/press_detail/12947.

85. The Frontier Post. (2019, August 14). Implementing RSS evil ideology. The Frontier Post. https://thefrontierpost.com/implementing-rss-evil-ideology/.

86. The Hindu, P. (2019, December 27). CAA, NRC may affect status of India's Muslim minority: Congressional Research Service. Retrieved April 25, 2020, from https://www.thehindu.com/news/international/caa-nrc-may-affect-status-ofindias-muslim-minority-congressional-researchservice/article30409109.ece\#: :text=\%E2\%80\%9CIn\%20tandem\%20with\%20a\% 20National,on\%20the\%20amended\%20Citizenship\%20law. 
87. TIMESOFINDIA.COM. (2019). Detention centres: All you need to know: India News - Times of India. Retrieved July 22, 2020, from https://timesofindia.indiatimes.com/india/detention-centres-all-you-need-toknow/articleshow/72938445.cms

88. Vision and Mission. (2012). Retrieved 9 July 2020, from http://rss.org/encyc/2012/10/22/rss-vision-and-mission.html

89. Whittam, J. (1996). Italian nationalism and Fascism. Retrieved 10 17, 2019, from http://research-information.bristol.ac.uk/en/publications/italian-nationalism-andfascism(8cde2546-edce-

90. Winter-Levy, S., \& Lalwani, N. (2018). When is nationalism a good thing? When it unites an ethnically diverse citizenry. Retrieved 9 July 2020, from https://www.washingtonpost.com/news/monkey-cage/wp/2018/06/26/when-isnationalism-a-good-thing-when-it-unites-an-ethnically-diverse-citizenry/

91. Zachariah, B. (2015). At the Fuzzy Edges of Fascism: Framing the Volk in India. South Asia-journal of South Asian Studies, 38(4), 639-655. Retrieved 10 17, 2019, from https://tandfonline.com/doi/full/10.1080/00856401.2015.1078948

92. Zain, O. F. (2009). Marginalization of Muslim Minority in India. Pakistan Journal of Social Sciences, 29(1), 101-106. Retrieved March 23, 2020, from https://pdfs.semanticscholar.org/be38/cad5042519594d9f4c20619d877108b13c9f. pdf

93. Zimmer, O. (2003). Homeland Nationalism Gone Wild: Nationalism and Fascism. Retrieved 10 17, 2019, from https://link.springer.com/chapter/10.1007/978-14039-4388-0_5 